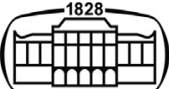

AKADÉMIAI KIADÓ

Acta Archaeologica Academiae Scientiarum Hungaricae

72 (2021) 1, 193-213

DOI:

10.1556/072.2021.00009

(c) 2021 The Author(s)

\section{ORIGINAL RESEARCH} PAPER

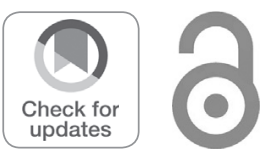

\title{
The monastery of Eusebius in Khirbet er-Ras (Kefar Truman)
}

\author{
Ayelet Dayan ${ }^{1}$ and Ádám Bollók ${ }^{2 *}$
}

${ }^{1}$ Israel Antiquities Authority, Levanda Str. 12, 6602919 Tel Aviv, Israel

${ }^{2}$ Eötvös Loránd Research Network, Research Centre for the Humanities, Institute of Archaeology, Tóth Kálmán u. 4, H-1097 Budapest, Hungary

Received: September 27, 2020 • Accepted: February 10, 2021

\begin{abstract}
The present paper publishes the archaeological remains of a monastery church excavated in 1958 at Khirbet er-Ras (Kefar Truman), Israel. The description of the architectural remains, including the threeaisled basilica and the structures surrounding it, is based on the archival documentation. This is followed by the detailed description and analysis of the church's mosaic pavements, preserved in the nave and in both side-aisles, with special emphasis on the mosaic decoration of the nave's central panel, set as a carpet design made up of florets enclosed by outlined scales, whose Levantine parallels are reviewed. In contrast to the sixth-century CE date proposed in previous reports, the setting of the floor is here placed into the third quarter of the fifth century CE based on Leah Di Segni's palaeographic date of the mosaic's inscription located in front of the sanctuary area. Using this revised date as a springboard for further discussion, a less linear stylistic development of mosaic floors covered by floral semis ornaments embedded in plain and outlined scales is suggested.
\end{abstract}

\section{KEYWORDS}

early Byzantine monastery church, late Antiquity, early Christianity in Judean shephelah, three-aisled basilica, mosaic, scale imbrication pattern, floral semis

\section{INTRODUCTION}

Khirbet er-Ras is located in the northern Judean shephelah, south of the road to Niblat, on the alluvial land of Kefar Truman (map ref. 1930/6540; $67 \mathrm{~m}$ asl). The ancient site of Khirbet er-Ras (Fig. 1) was identified following the discovery of the remains of a church (including mosaic pavements), foundations of fieldstones, and pottery from the Byzantine and Early Islamic periods. ${ }^{1}$

The site was first excavated in 1958 by Varda Sussman on behalf of the Department of Antiquities. Beside the documentation of a winepress and a cistern filled with soil as well as of the ruins of ancient buildings visible on the ground, the most important discovery was that of the remains of an early Christian monastery church paved with mosaics (Fig. 2). ${ }^{2}$ Unfortunately, except for the subsurface foundation walls, almost nothing of the built structures of the church was left intact. Most of the walls appear to have been destroyed already in ancient times and by later agricultural activity.

${ }^{1}$ For the location of the site, see PEF map 1880 s.v. Kh. Er Râs; OvadiaH 1970, 101-102 No. 94; CoHEN 1975, 309; Bagatti 1983, 175; Ovadiah-Ovadiah 1987, 90, No. 146; TsafriR-Di et al. 1994, 166; Gophna-Beit-ArieH 1997, 63, Site 124; BAGATTI 2002, 211.

*Corresponding-author.

${ }^{2}$ In September 1958, B. Isserlin, the antiquities inspector of the Central Region in Israel, discovered the mosaic floor with the Greek inscription on the lands of Kefar Truman. The information about the fieldwork is presented here is the courtesy of Varda Sussman, to whom we are grateful for allowing us to publish the results of her excavation as well as the data she collected during the fieldwork. Her field notes are kept in the Israel Antiquities Authority archives under "Scientific Supervision Folder: P/Kefar Truman/X; Folder of excavation files: Kefar Truman, Varda Sussman, \&-21/1958". 


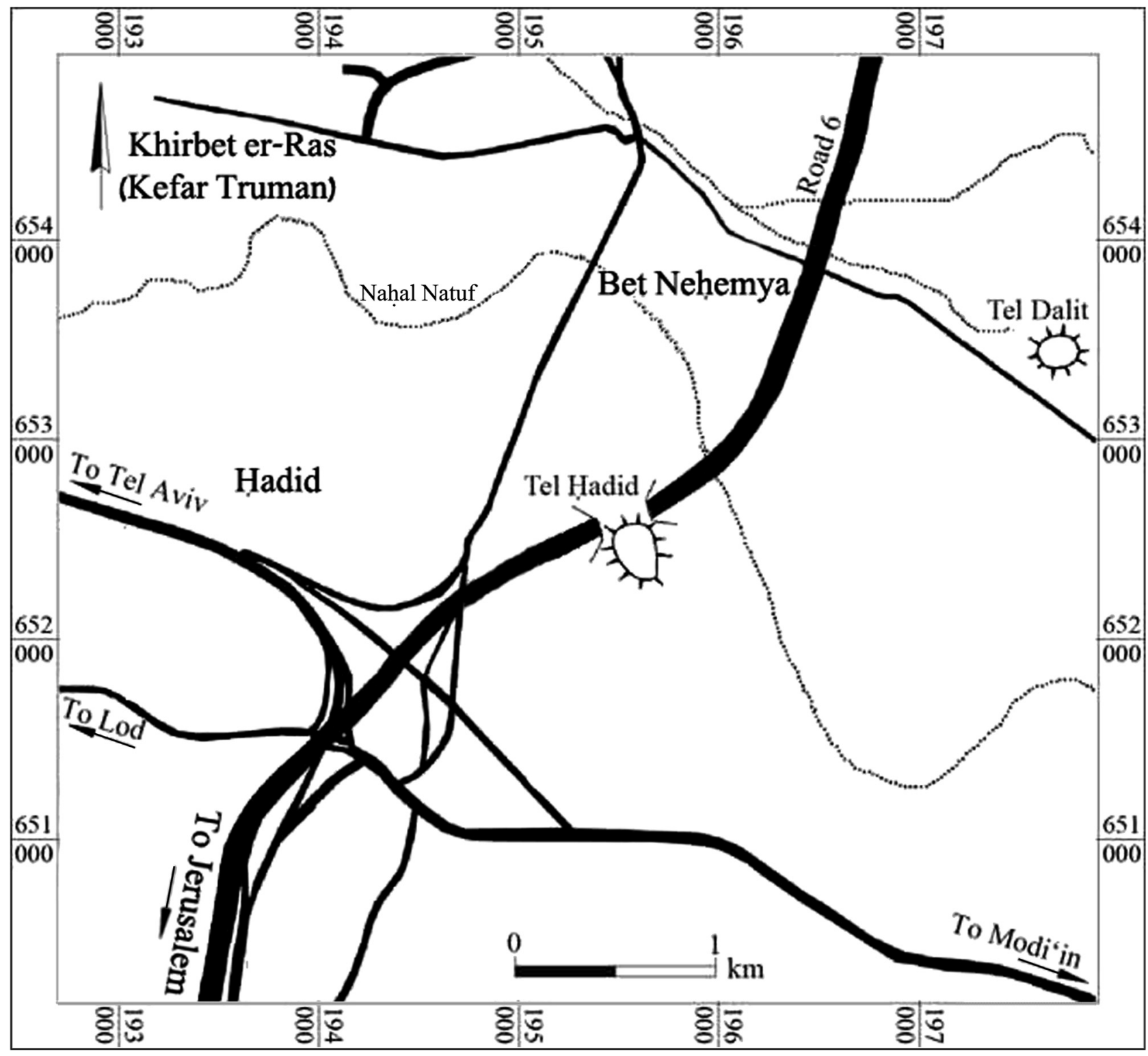

Fig. 1. The location of Khirbet el-Ras (Kefar Truman)

Further wall and floor remains of the Byzantine period were documented in the course of a later excavation conducted on the same site, but at some distance from the location of Sussman's original dig. ${ }^{3}$ The preserved remains were assigned to two different chronological phases. Walls built of fieldstones and floor sections composed of flat stones were dated to the later (upper) phase. Another fieldstone wall represented the earlier (lower) phase alongside another wall covered with stone on the outside and filled up with soil. A sunken oval hearth with a step in its northern section likewise dated from this phase. Unfortunately, it was impossible to identify a larger coherent structure based on the above-described elements.

Even though the Kefar Truman mosaics have been mentioned in short reports and have been very briefly

${ }^{3}$ Oren-SCheftelowitz 2000. described in several catalogue entries during the past half century, ${ }^{4}$ no detailed publication of the site has appeared to date. The present paper thus seeks to make V. Sussman's excavation results available to the public.

\section{THE MONASTERY}

\section{The excavated structure}

The three-aisled basilica was oriented towards the east (Fig. 2). Even though the building's eastern section was not completely excavated, its main elements were uncovered

${ }^{4}$ Biran 1959, 32; Yeivin 1960, 46; Zvilichovsky 1960; Ovadiah 1970, 101-102, No. 94; Cohen 1975, 309; Ovadiah-Ovadiah 1987, 90, No. 146; SChick 1995, 364; BaGATti 2002, 211; MAdDEN 2014, 95 , No. 129. 


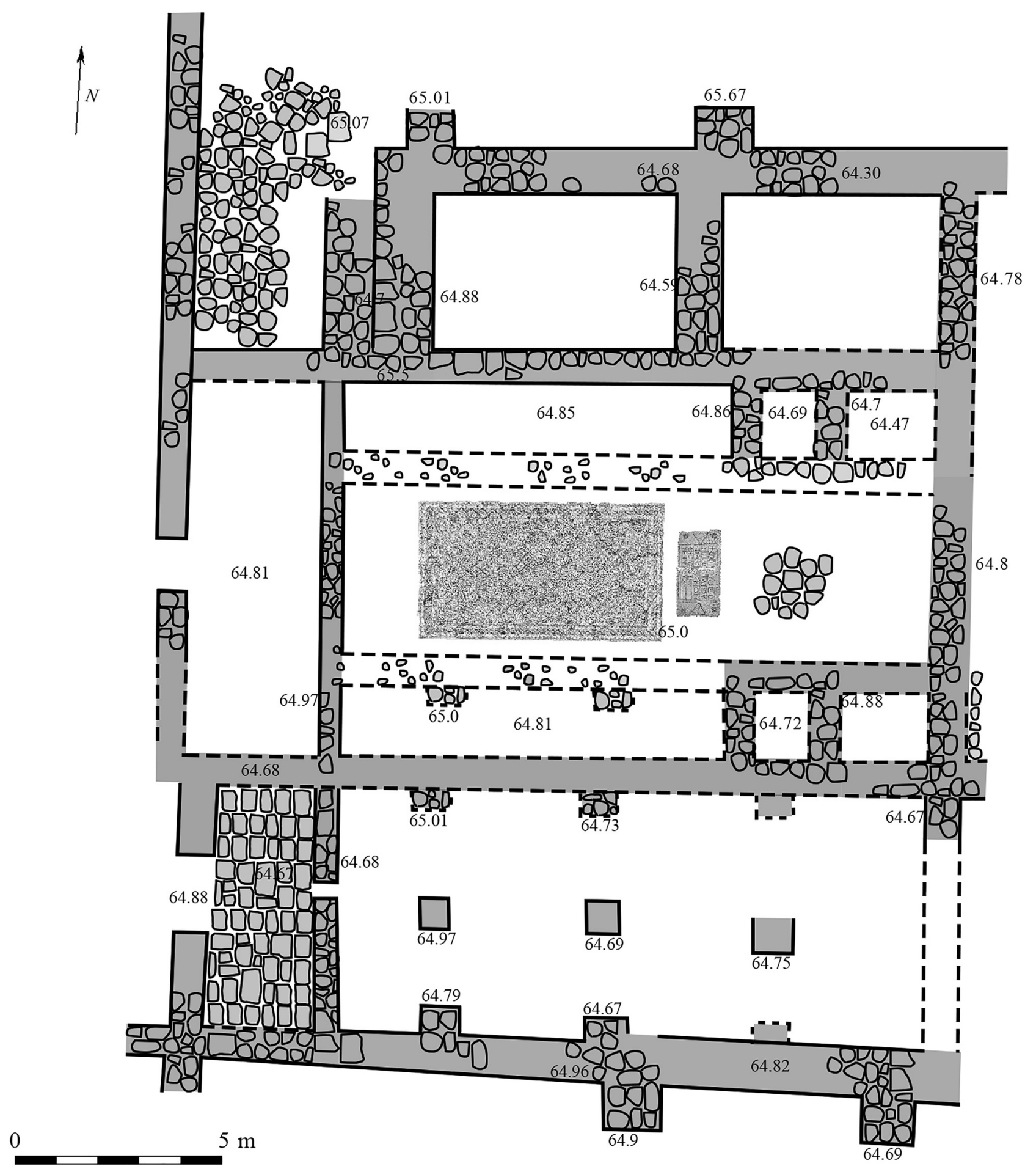

Fig. 2. Plan of the church with its annexes (drawn by Magda Éber (Institute of Archaeology, Research Centre for the Humanities) after V. Sussman's original plan, kept in the Israel Antiquities Authority Archives, Folder of excavation files: Kefar Truman, Varda Sussman, $\&-21 / 1958)$

during the dig. The basilica had a central nave measuring $4.32 \times 9.50 \mathrm{~m}$ and two identical side aisles $(1.73 \times 9.50 \mathrm{~m}$ each). According to the original field record, both pastophoria rooms (diaconicon: $1.4 \times 1.7 \mathrm{~m}$, prothesis: $1.73 \times$ $2.10 \mathrm{~m}$ ) were uncovered during the excavation. Although the original ground plan appended to the field report (on which Fig. 2 is based) indicates a possible internal division both within the prothesis and the diaconicon, no further information is available on this. Between the two pastophoria, the one-time existence of a paved surface, the location of the apse and the steps leading to it from the nave can be reconstructed, of which, however, hardly anything has survived. Thus, it is difficult to determine the original shape of the apse. Given that no clear evidence pointing to the one- 


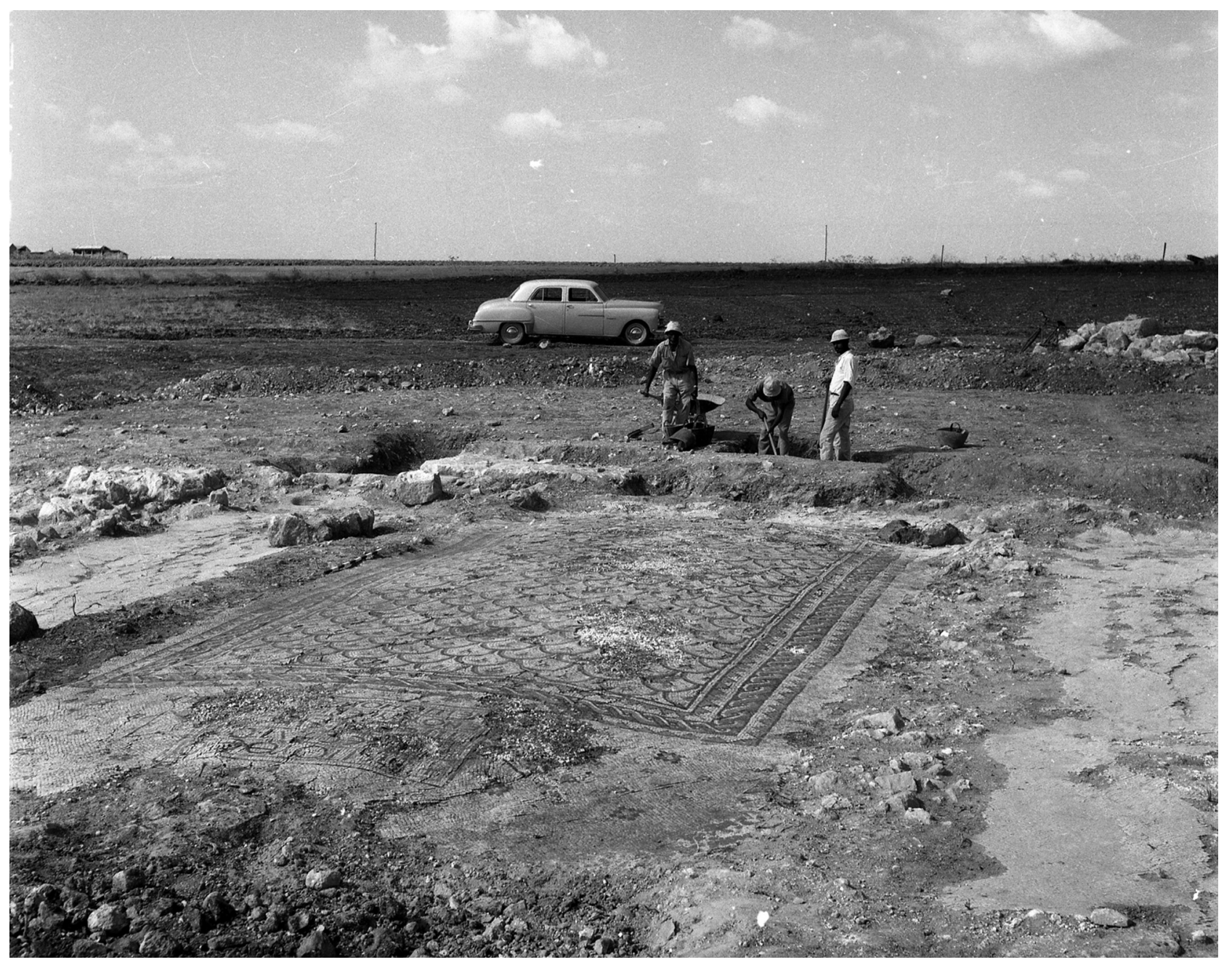

Fig. 3. The church with its mosaic floors during the excavation, seen from the north-east (photo: Israel Antiquities Authority Photo Archive; No. 23301)

time existence of an internal apse was documented, it is possible that the church originally had a rectangular instead of a regular round apse. ${ }^{5}$ However, there is also the possibility that no architectonically distinct apse was built, as in the case of the Horvath Hermeshit church. ${ }^{6}$ The area where the apse is assumed to have been was paved and there must once have been a screen in the front of the space with the mosaic inscription (see below).

As customary, the narthex is located on the western side of the basilica $(3.2 \times 9.1 \mathrm{~m})$. Since the above-ground walls of the church are missing, it is impossible to identify the location and number of the entrance(s). It may be surmised that there was a single main entrance. Neither have any traces of one or possibly more entrances leading from the narthex to the basilica been found, nor of column bases, nor of walls that separated the nave from the aisles. The single indication of the separation of the central and side spaces is the marked discontinuity of the excavated mosaic pavements. As is

${ }^{5} \mathrm{Cf}$. Weber 2010.

${ }^{6}$ See GreENHut 1998. clearly visible on the archival photos taken at the time of the excavation (Figs 3 and 4), the central rectangular paved area is unmistakably separated from the mosaics of the aisles by a ca. $0.65 \mathrm{~m}$ wide unpaved strip, covered with earth on the photos, on its southern side, and another $c a .0 .7 \mathrm{~m}$ wide strip, filled with earth and fairly irregular stone blocks, on its northern side. The majority of the stones from this area were probably removed for recycling as building material in later periods. Since the aisles are quite narrow, perhaps one main entrance served the entire basilica.

Additionally, two wings, a northern and a southern one, were identified during the excavation. They are neither identical in terms of their plan, nor were they precisely adapted to the dimensions of the basilica.

The internal dimensions of the northern wing are $3.65 \mathrm{~m}$ wide by $11.5 \mathrm{~m}$ long (if the walls are included, the external dimensions are $5.4 \mathrm{~m}$ by $15 \mathrm{~m}$ ). Traces of an internal dividing wall were also uncovered, which divided the building into two larger rooms. Similarly to the main church, neither the entrance of the northern wing, nor the door of the internal dividing wall could be identified. No substantial traces of the original wall were found on the 


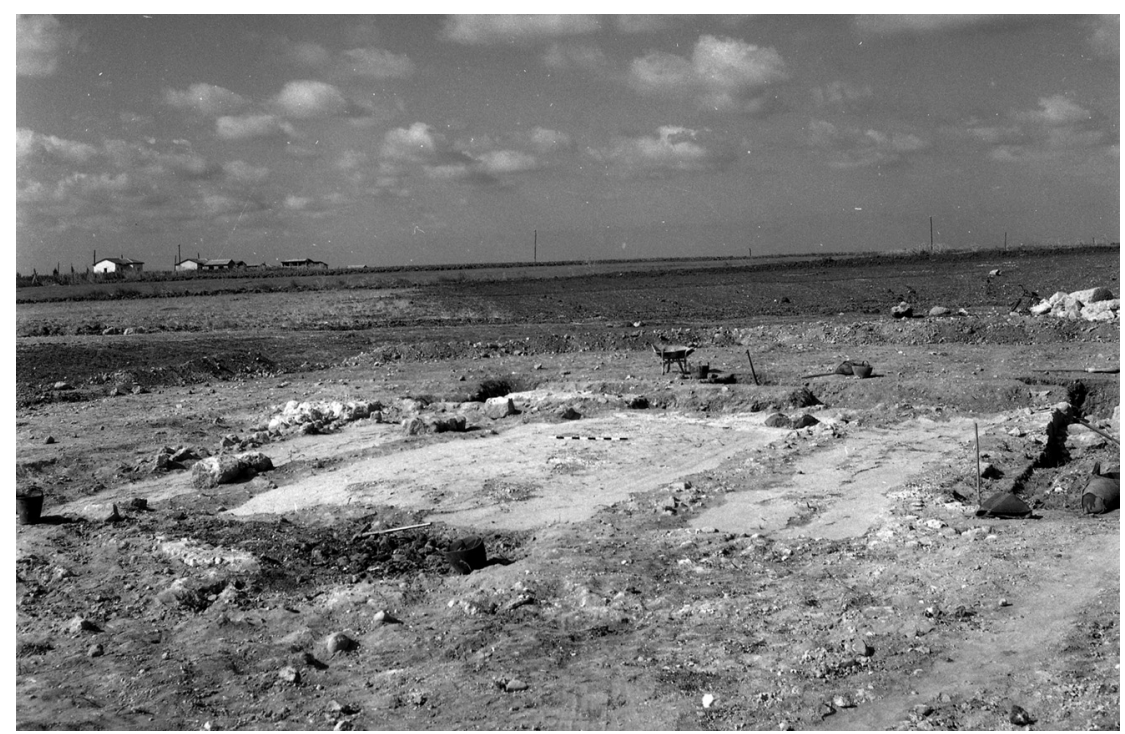

Fig. 4. The church during the excavation, seen from the north-east (photo: Israel Antiquities Authority Photo Archive; No. 23293)

northern side, although the presence of several stones seems to indicate the wall's original line. Likewise, additional stones appear to mark the one-time existence of two supporting columns attached to the wall from the outside. There is a courtyard paved with large stones along the western façade (Fig. 5). Here, the width of the building's western wall was enlarged to $2.6 \mathrm{~m}$, possibly reinforced after an earthquake, or to provide support at a time when the northern courtyard was covered with a roof.

The southern wing was $5.6 \mathrm{~m}$ wide and extended along the length of the basilica, i.e. it had a length of $18.5 \mathrm{~m}$. As in the case of the northern wing, a courtyard paved with carefully laid large stones adjoined its western wall. The walls, the entrance to the main courtyard ( $2 \mathrm{~m}$ in width) and the threshold of the door $(0.2 \mathrm{~m}$ above the floor level) were preserved here. According to the original field record, traces

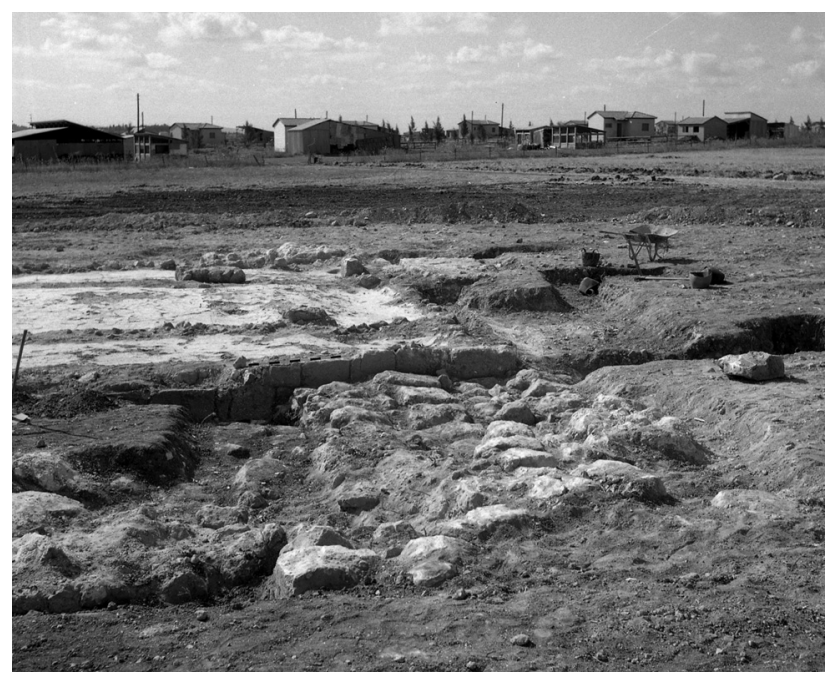

Fig. 5. The pavement of the northern courtyard, seen from the north (photo: Israel Antiquities Authority Photo Archive; No. 23297) of an entrance (2.8 $\mathrm{m}$ in width) paved with stones similar to those of the courtyard leading from the courtyard to the nave were also identified (although not recorded on the ground plan). The eastern hall had three rows of columns, each with two columns attached to the longer walls and a single one in the hall's central longitudinal axis. Only the foundations of the central pillars remained of the three columns. The columns were built of large stones, in all probability as necessary supports of the roof. The eastern wall of the hall was not discovered, and the walls continued eastward. It seems likely that there were entrances from the wings to the main basilica, but their secure traces, if any, were impossible to document in the course of the excavation. The only wall that was well preserved was at the western end of the northern wing. It was excavated to a depth of $2 \mathrm{~m}$ below the surface (Fig. 6). A pair of identical columns supported the outer wall of the southern wing, too.

The stones used for the construction of the building were most probably quarried from the nearby hills. Remains of plaster were discovered on the walls, indicating that they had been plastered on the inner sides. A small number of roof tiles were also discovered, and thus it can be assumed that the structure was covered with a tiled roof. Based on the method and style in which the walls were built, the excavator concluded that the northern and southern wings were probably added to the basilica later, some time after its initial construction. According to the original field report, traces of a later structure erected in the narthex were likewise discovered. There was another structure near the entrance to the southern wing that was connected to the southern wall of the basilica. Neither the date, nor the exact function of these later structures can be established with any degree of certainty.

\section{The mosaic floors}

The narthex was paved with white tesserae of $c a .2 \times 2 \mathrm{~cm}$ in size. The excavator noted that the presence of carelessly 


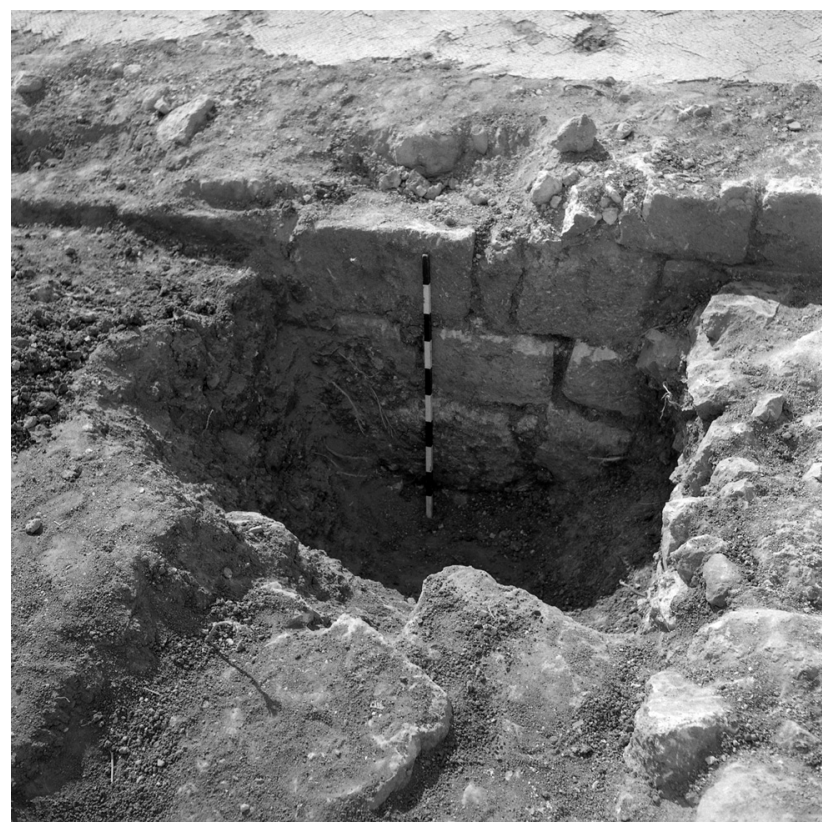

Fig. 6. Foundations walls at the western end of the northern wing (photo: Israel Antiquities Authority Photo Archive; No. 23298)

laid larger stones probably indicated later repairs. (This part of the mosaic pavement is not visible on the available archival photos, and neither was it kept for conservation and preservation.)

The mosaic of the nave (Figs 2-4 and 8) is made up of a large central decorative panel, framed with mosaic strips made of white tesserae. The mosaic stones are often roughly cut and, accordingly, irregular in shape. Their sizes range from $c a .1 .2 \times 1.2 \mathrm{~cm}$ to $c a .1 .8 \times 2 \mathrm{~cm}$, their majority being around ca. $1.5 \times 1.5 \mathrm{~cm}$.

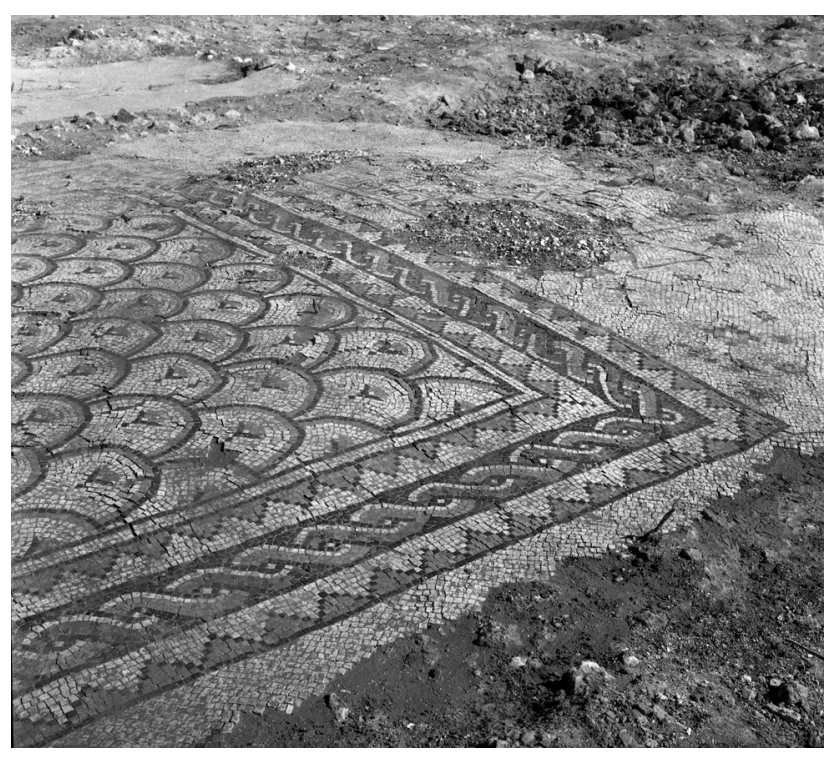

Fig. 7. The tripartite frame of the central mosaic panel of the nave at the time of the excavation, seen from the south (photo: Israel Antiquities Authority Photo Archive; No. 23302)

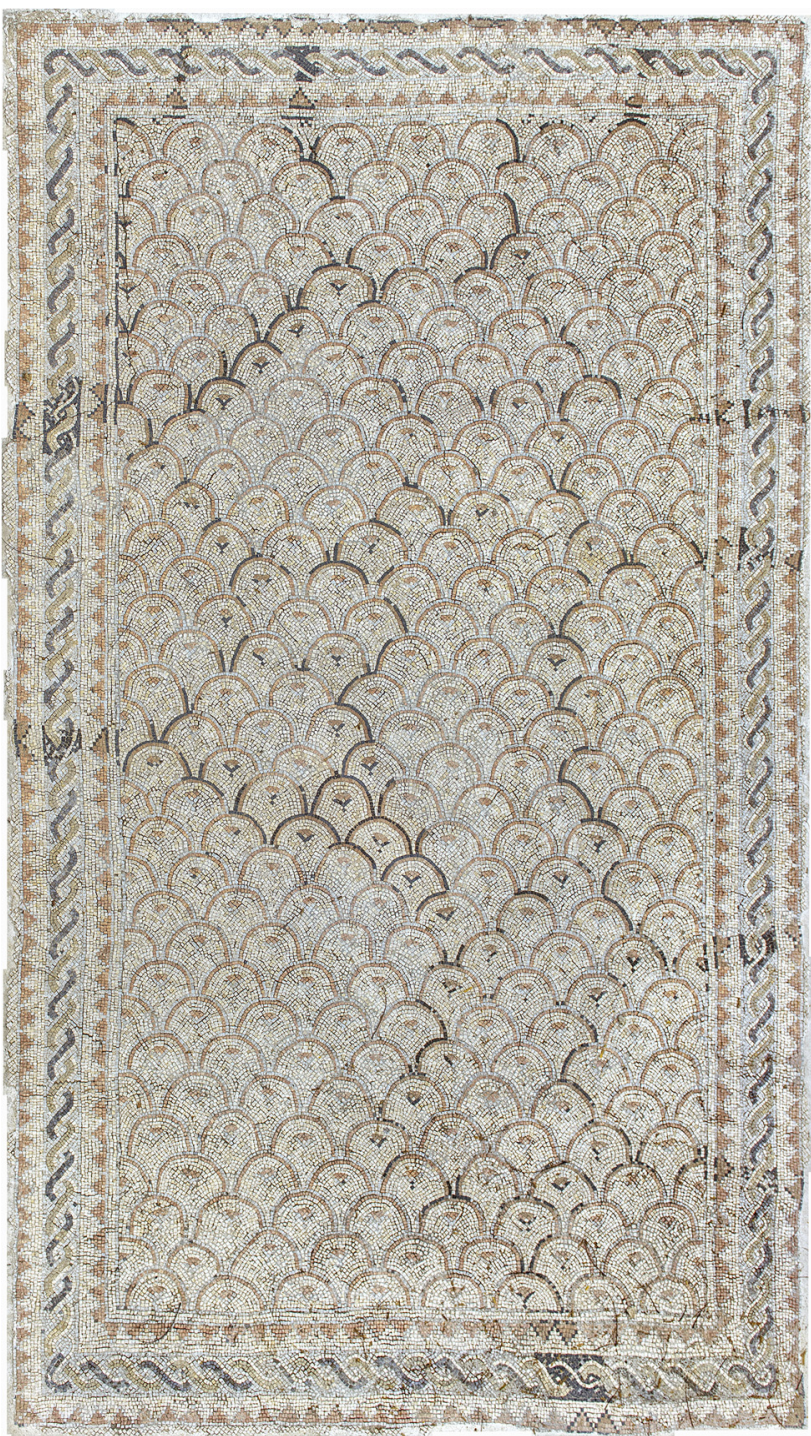

Fig. 8. The central mosaic panel of the nave (photo: Leonid Padrul-Kwitkowski, @ MUSA - Eretz Israel Museum, Tel Aviv)

The white mosaic strips framing the central panel on the northern and southern sides are fairly narrow in width and do not bear any decorative motifs (Figs 3-8). In contrast, the wider strips at the western and the eastern ends of the central carpet, near the entrance of the church and in front of the sanctuary area (Fig. 7), are further decorated with lozenges in two alternating sizes, made of brick red and black tesserae on a white background according to the following pattern (Class $\mathrm{E}$ in Avi-Yonah's classification ${ }^{7}$ ). The centres of the lozenges are made up of either one or four white mosaic stones. Brick red squares, each made up of one or four mosaic stones, were set on the four sides of these white squares, while the outer three sides of the brick red squares were flanked by black squares, each made up of either one or four tesserae as shown on Fig. 9.2. The sizes of the larger lozenges flanking a tabula ansata (see below) vary between $c a .14 \times 14 \mathrm{~cm}$ and $c a .16 \times 16 \mathrm{~cm}$. (The smaller

${ }^{7}$ Avi-Yonah 1981, 285. 

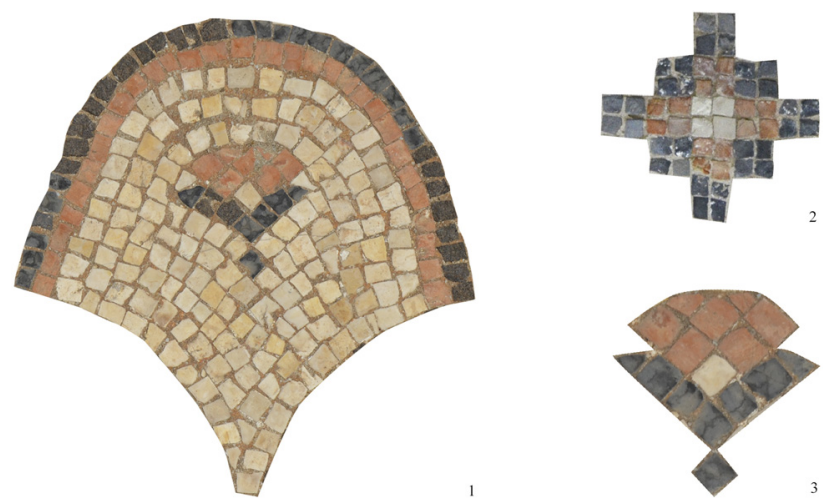

Fig. 9. Decorative elements of the mosaic carpet of the nave (photo: Ádám Bollók)

lozenges clearly visible on the archival photo [Fig. 7] were not included in the preserved panel measuring $\mathrm{ca} .106 \times 217 \mathrm{~cm}$, housed in the Rockefeller Archaeological Museum. ${ }^{8}$ )

The only major difference between the mosaic strips at the western and the eastern ends of the central carpet is that the latter, located in front of the sanctuary area, contains a five-line Greek inscription enclosed by a tabula ansata (ca. $93.5 \times 143.5 \mathrm{~cm}$ in size, Figs 7 and 10, see below). The letters vary from $c a .10 \mathrm{~cm}-15 \mathrm{~cm}$ in height, their majority falling between $c a .12 \mathrm{~cm}$ and $13 \mathrm{~cm}$, and are set in black tesserae against a white ground. The bands enclosing the letters are $c a .12-13 \mathrm{~cm}$ to $16-17 \mathrm{~cm}$ in height (decreasing in height from top to bottom) and made up of white tesserae. The lines framing the entire inscription as well as the ones separating the single bands are of brick red stones, set in one row. The latter lines are separated by a double line of white tesserae $(c a .3 .0-3.5 \mathrm{~cm})$ from the black outline of the tabula ansata framing the composition. The bases of the triangular "hands" of the tabula ansata are $38 \mathrm{~cm}-40 \mathrm{~cm}$ in length, while the two other sides are 33.5 $\mathrm{cm}-35.5 \mathrm{~cm}$ in length. The triangles are outlined with black stones in one row on a white ground, and both include three black tesserae attached to the line of the base and a small rosette made up of five brick red stones $(5.5-6.5 \mathrm{~cm}$ in height) in the third of the triangle closer to the inscriptional field.

The central panel (Fig. 8) is framed by a tripartite border (Figs 7 and 11), whose outer framing lines are made of black tesserae in one row. ${ }^{9}$ Identical black lines frame the border's central band, too, which is filled with a finely made simple

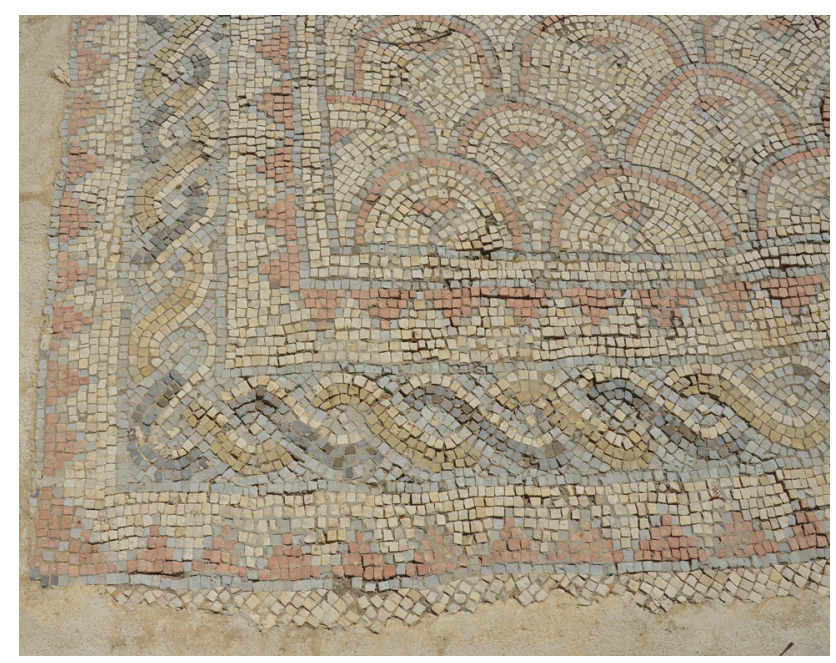

Fig. 11. The tripartite frame of the mosaic panel of the nave (photo: Ádám Bollók, @ Eretz Israel Museum, Tel Aviv)

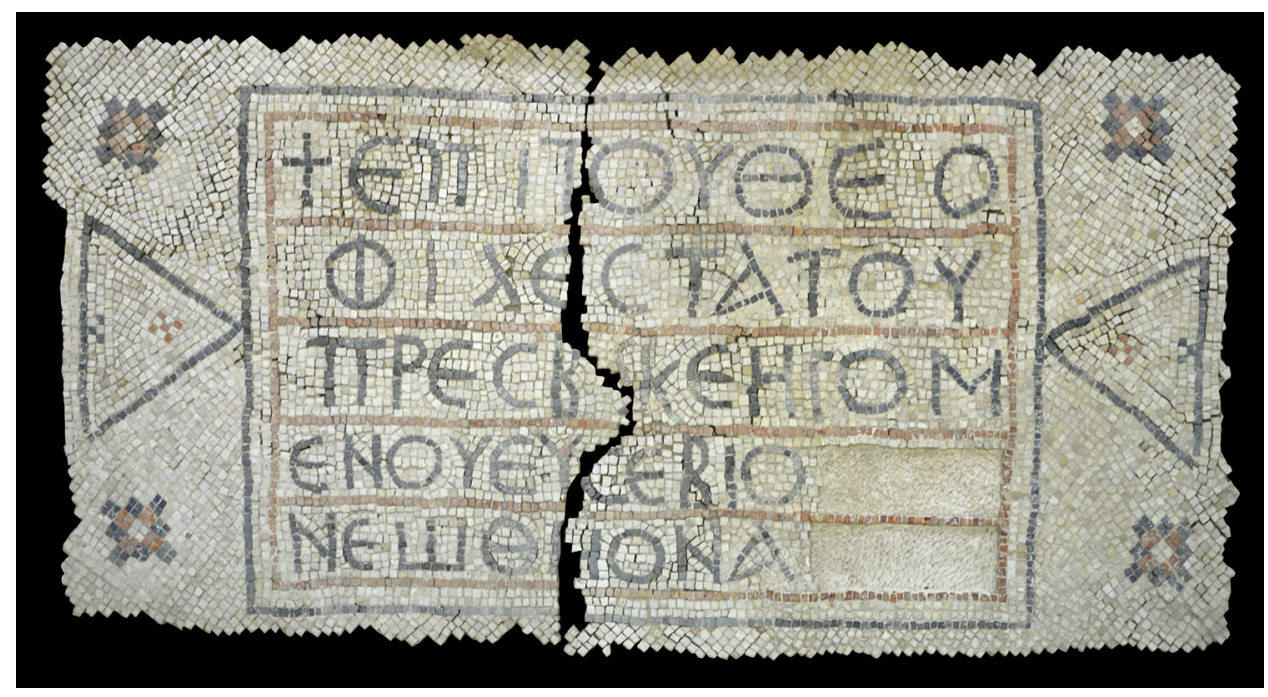

Fig. 10. Mosaic panel of the nave with the Greek inscription (photo: Ádám Bollók, @ IAA)

\footnotetext{
${ }^{8}$ Rockefeller Archaeological Museum (Jerusalem), Inv. No. 1958-829. We are especially grateful to Alegre Savariego, Curator of the Rockefeller Collections and Mosaics, for providing an opportunity to examine the preserved panel.
}

${ }^{9}$ The central panel is currently kept and exhibited in the Eretz Israel Museum in Tel Aviv. We are particularly grateful to Nitza Bashkin, Curator of the Eretz Israel Museum Mosaics, for granting us access to the mosaic. 
guilloche ornament (Class B2 in Avi-Yonah's classification, ${ }^{10}$ a type of interlace or Flechband ornament) crafted from white, brick red, mustard, and black mosaic stones $(\mathrm{ca} .18 \mathrm{~cm}-21 \mathrm{~cm}$ in width). Both the outer and the inner bands enclosing the central band are identical (the inner being $11 \mathrm{~cm}-14 \mathrm{~cm}$, while the outer $13 \mathrm{~cm}-15 \mathrm{~cm}$ in width): rhythmically placed triangles follow each other along the entire composition (Classes A5 and A6 in Avi-Yonah's classification ${ }^{11}$ ). Their bases are constituted by the border's outer black lines. The triangles' outlines are likewise made up of identical black tesserae. The inner spaces are filled with brick red mosaic stones (up to four tesserae, i.e. $5.5 \mathrm{~cm}-7 \mathrm{~cm}$ in height). Strictly speaking, the border is tripartite, to which a fourth and final element is attached, which separates the border from the central field of the central panel and which is made up of two lines of plain white tesserae flanked by the inner black outline of the border and the outer black outline enclosing the central field.

The central field $(c a .281 \times 573 \mathrm{~cm})$ framed by the mentioned single line of black tesserae and enclosed by the above-described border is evenly filled with floral semis, made up of the repetition of small vegetal ornaments against a scalepattern background (Fig. 9.1; Class J3 in Avi-Yonah's classification $^{12}$ ). The entire composition is set against a white ground. The scales are outlined, the outer lines are marked with a line of black, while the inner lines with another line of brick red tesserae. The small floral ornaments in the centres of the scales are crafted according to the following pattern (Fig. 9.3): their short stems are marked by single black mosaic stones, each calyx is created out of five whole and two halved black tesserae arranged in $\mathrm{V}$-shapes, while the petals are formed of five whole and two halved brick red stones. The heights and the widths of the floral motifs are $8 \mathrm{~cm}-10 \mathrm{~cm}$ and $9 \mathrm{~cm}-10 \mathrm{~cm}$, respectively, while the heights of the scales vary between $c a .33 \mathrm{~cm}$ and $38 \mathrm{~cm}$. When viewed from a certain distance (Fig. 12), the unevenness of the scale pattern's distribution is not particularly noticeable; however, a closer look quickly reveals its oddities. Taken together with the medium size and rough workmanship of the tesserae, however, it amply illustrates the pavement's mediocre quality.

Besides the eastern and the western ends of the nave mosaic, the simple lozenges recur in the eastern section of the southern aisle's pavement, too (Fig. 13). (Neither of the aisles' mosaics are preserved.) According to the excavator's notes, the latter mosaic was divided into three different sections, of which the available archival photos document only the eastern part (Fig. 13), as well as the westernmost extremity of the pavement, where a $c a .40 \mathrm{~cm}$ wide and $c a$. 20-25 cm deep depression for collecting water, paved with white mosaic tesserae, was preserved (Figs 14 and 15). ${ }^{13}$ The pavement in the northern aisle was divided into two sections according to its decorative pattern.

\footnotetext{
${ }^{10} \mathrm{Avi}$-Yonah 1981, 285.

${ }^{11}$ Avi-Yonah 1981, 285.

${ }^{12}$ Avi-YoNAH 1981, 288.

${ }^{13}$ For parallels, see, e.g., Avi-YoNAH 1960, Pl. XII.1; AcCONCI 1998, 533, Fig. 165a
}

All decorative elements of the above-described pavements enjoyed extremely wide popularity in the mosaic art of the late antique eastern Mediterranean in general and particularly in the provinces of Palaestina Prima, Palaestina Secunda and Arabia. The semis of the nave's central panel embedded into the scale imbrication pattern background was one of the highly popular mosaic carpet designs from the fifth century onwards. ${ }^{14}$ It was employed both as a self-contained decorative element, as in our church, and as a background to animal figures and animal combat scenes integrated into the carpet design, as on the famous fifth-century Phoenix mosaic at Antioch, ${ }^{15}$ a fifth-century mosaic from the environs of Hama, ${ }^{16}$ the pavement of the later fifth-century Michaelion at Huarta, ${ }^{17}$ the late fifth-earlier sixth-century pavement in a private house in Androna, ${ }^{18}$ and the narthex mosaic of a sixth-century church at Hanita, ${ }^{19}$ to name merely a few examples. ${ }^{20}$ Scale patterns were created using both plain and outlined versions of the scales, but one pavement always used solely one of the two types. For understandable reasons, the scales' plain variant was preferred when creating a background for an animal imagery, while outlined scales predominate in panels without additional figures.

Focussing now on the pattern's independent usage, several close counterparts of our mosaic can be mentioned both from Palaestine Prima, the Byzantine province in which our site is located, and from more distant regions of the eastern Mediterranean. To begin our overview with examples closer to our site in geographical terms, mention may be made of the province's most important political and cultural centres, Caesarea and Jerusalem. In the provincial capital, both plain and outlined scales with florets appear on at least three pavements in the city's northern area: on a mosaic of the Samaritan synagogue erected east of the Byzantine dux' palace, ${ }^{21}$ as well as on two pavements of a large luxurious private mansion, including the finely crafted mosaic of a long corridor. ${ }^{22}$ Several church buildings are likewise known to have been decorated with this pattern in Jerusalem. It covered the entire northern aisle of a church erected on the Mount of Olives, ${ }^{23}$ and it appears among

\footnotetext{
${ }^{14}$ For the forms and development of carpet designs in the mosaic art of the region and the period, see the recent overview in TALGAM 2014.

${ }^{15}$ LeVI 1947, 351-352, Pls LXXXIII, CXXXIVa.

${ }^{16}$ ZAKZOUK 2008, 132, Abb. 2.

${ }^{17}$ Canivet-Canivet 1987, Pl. CXX-CXXVII; Balty 2008, 102, Abb. 4.

${ }^{18}$ Strube 2008, 59, 70, Fig. 30; Strube 2010, 234, Abb. 33.

${ }^{19}$ Barash 1974, Ovadiah-Ovadiah 1987, 66, Pls LXIX.1, LXX.2; Talgam 2014, 116, Fig. 162.

${ }^{20}$ For further examples, see LAVIN 1963, 195; DonCEEL-VOÛTE 1988, 6977, Fig. 43 (Dibsī Faraj), 138-145, Fig. 116 (Tell Huwayd), 145-150, Fig. 119 (Huwayjat Halāwa), 178-186, Figs 150, 156, 159 (Mazra'at al-'Ulyā), 193-201, Figs 170-172 (Khirbat Umm Hāratayn), 385-392, Fig. 376 (Khān Khalda); ÇELIK 2018, 273, Fig. 4. For the pattern's emergence and development, see also KITZINGER 1977, 89-90.

${ }^{21}$ PAtrich 2011, 213, Fig. 118; PATrich 2018, 46.

${ }^{22}$ PATRICH 2011, 139, Fig. 75.

${ }^{23}$ Bliss-Dickie 1898, 214-215, Pl. XX; Avi-YonAH 1981, 313-314, No. 115.
} 


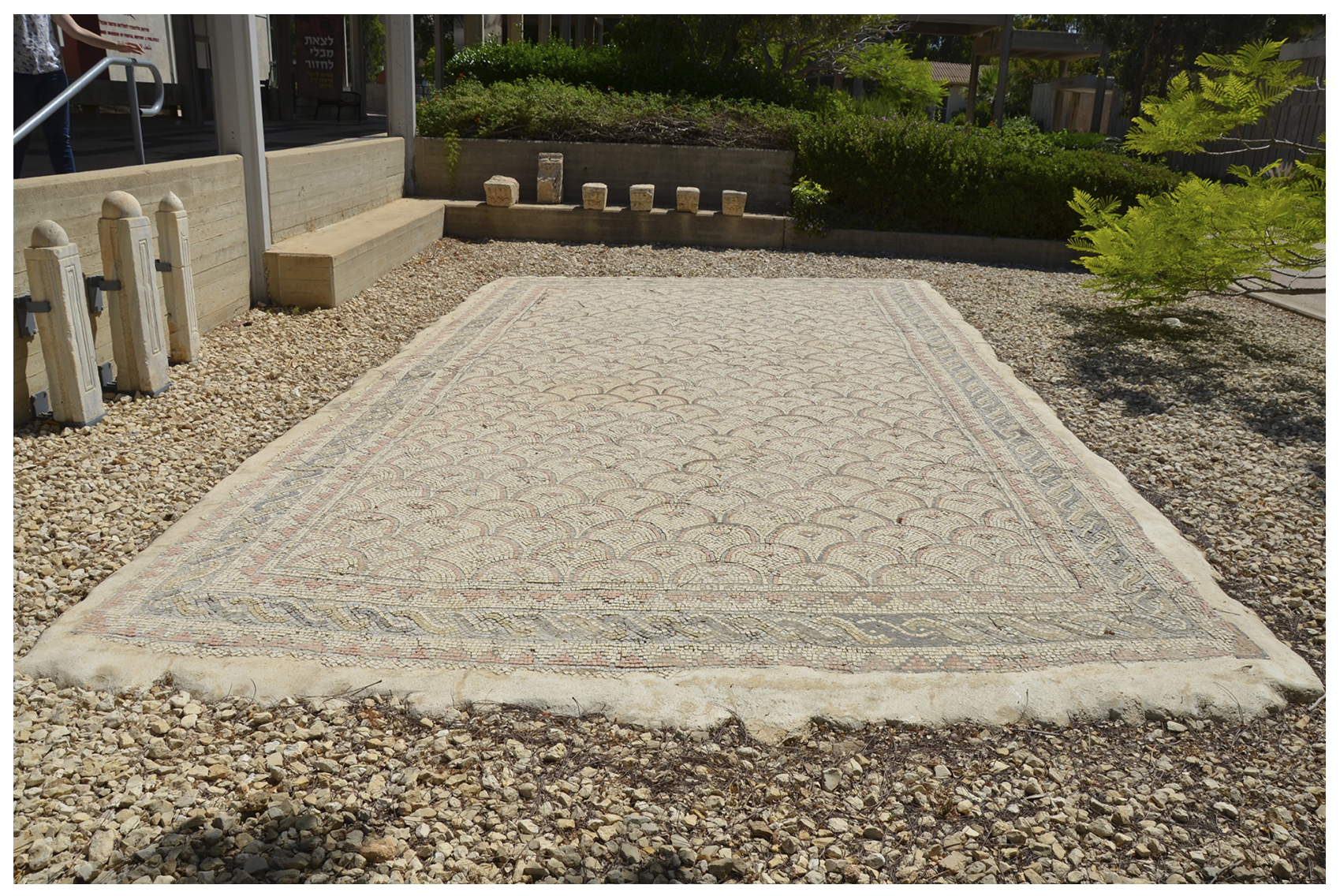

Fig. 12. The mosaic carpet of the nave seen from a certain distance (photo: Ádám Bollók, (C Eretz Israel Museum, Tel Aviv)

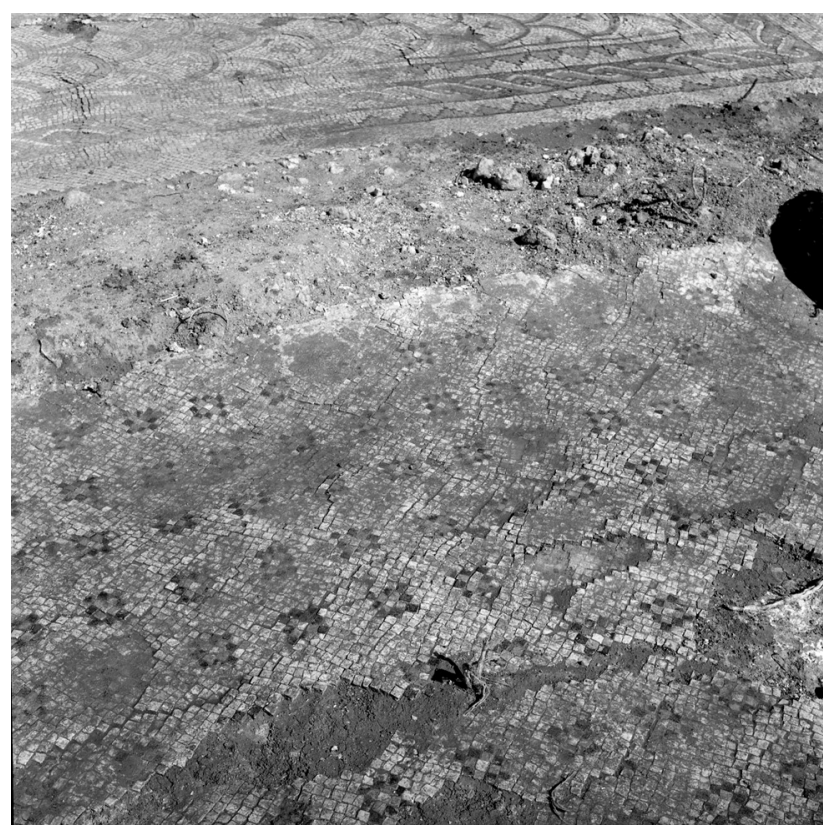

Fig. 13. The eastern section of the mosaic panel of the southern aisle (photo: Israel Antiquities Authority Photo Archive; No. 23300)

the mosaics of the Church of Eleona, not far from the former, ${ }^{24}$ on the mosaics in the nave and the northern and the southern

\footnotetext{
${ }^{24}$ Avi-Yonah 1981, 313, No. 113.10.
}

aisles of the fifth-century Church of the Siloam Pool, ${ }^{25}$ and in the northern apse of a church on Mount Zion. ${ }^{26}$

The same pattern was also employed by the mosaicists working in the wider area of Jerusalem. For example, it can be found on the sixth-century mosaics of 'Room 1' of a monastic complex at Khān Saliba, east of the Holy City. ${ }^{27}$ It also appears in the narthex and the southern aisle of a church in "Ayn al-Hanniya, ca. $7 \mathrm{~km}$ south-west of Jerusalem, ${ }^{28}$ in the southern aisle of the mid-to later fifth-century Northern Church of the Herodion, ${ }^{29}$ on the narthex mosaic of the fifthcentury Cave Church and on one of the bema panels in the sixth-century basilica at the Shepherds' Field ${ }^{30}$ as well as among the mosaics of the monastery at Khirbat Siyar alGhanam $^{31}$ and of a church (?) at Khirbet Luqa. ${ }^{32}$ Outlined

${ }^{25}$ Bliss-Dickie 1898, 189; Avi-Yonah 1981, 311, No. 107.2-3; Madden 2014, 93.

${ }^{26}$ Tushingham $1985, \quad 73, \quad 472, \quad$ Pl. $\quad 72 ; \quad$ Campbell 1985 ; Ovadiah-Ovadiah 1987, 83, Pl. XCV.

${ }^{27}$ Prignaud 1963, Pl. XI; Ovadiah-Ovadiah 1987, 91.

${ }^{28}$ Baramki 1934, Pl. XXXVIII.2, Madden 2014, 59.

${ }^{29}$ NetZer 1990, 167-169, Plan 3, Figs 5-6; NetZer et al. 1993, 222-223.

${ }^{30}$ Tzaferis 1975, 9, Pl. 1.3; Ovadiah-Ovadiah 1987, 24; Madden 2014, 124.

${ }^{31}$ MAdDEN 2014, 128.

${ }^{32}$ Corbo 1955, 147, Tav. 49, Fot. 159-160; Ovadiah-Ovadiah 1987 , 97. 


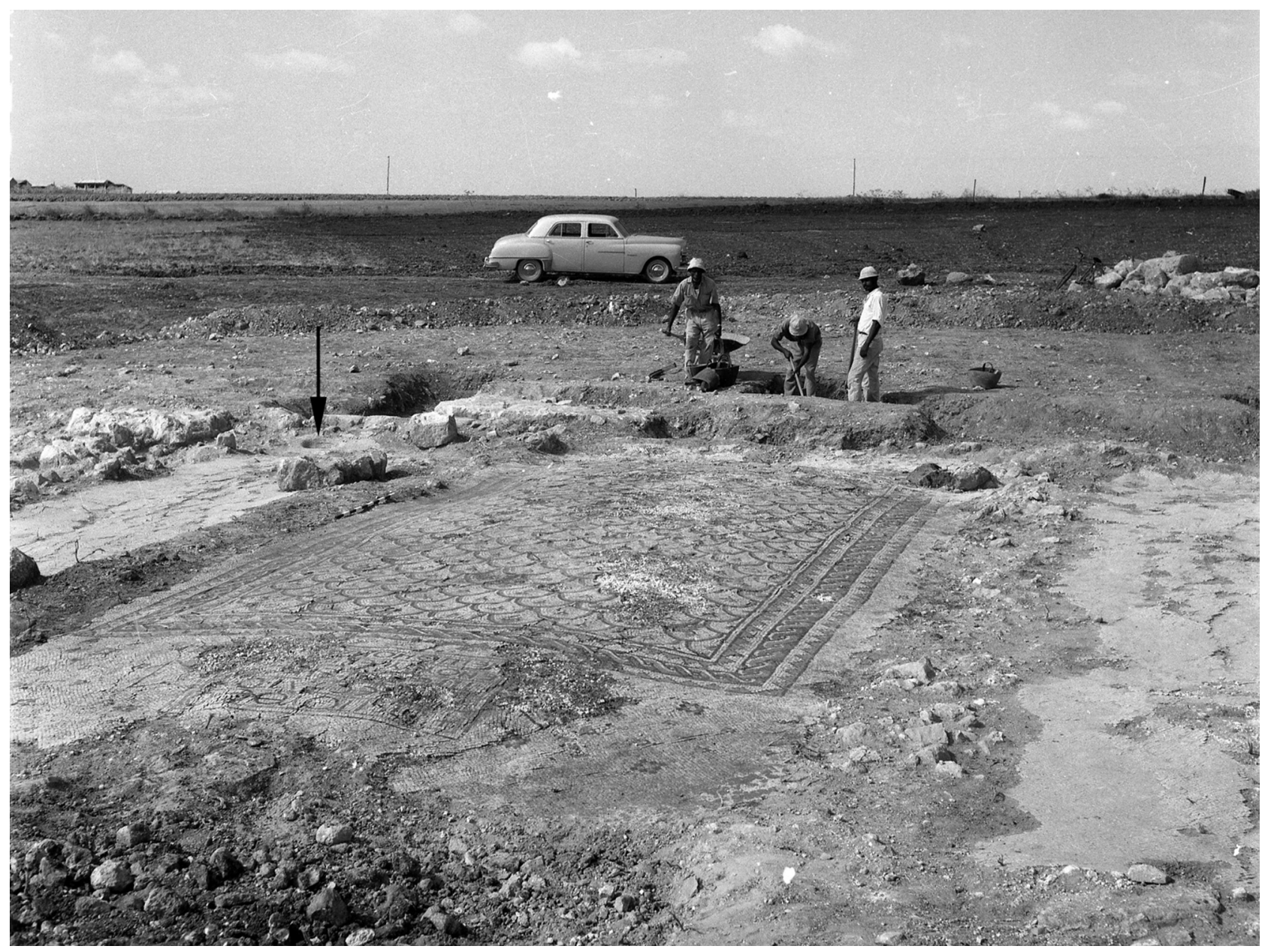

Fig. 14. The church during excavation, seen from the north-east, with the paved depression at the south-western end of the mosaic pavement of the southern aisle (marked with black arrow) (photo: Israel Antiquities Authority Photo Archive; No. 23293)

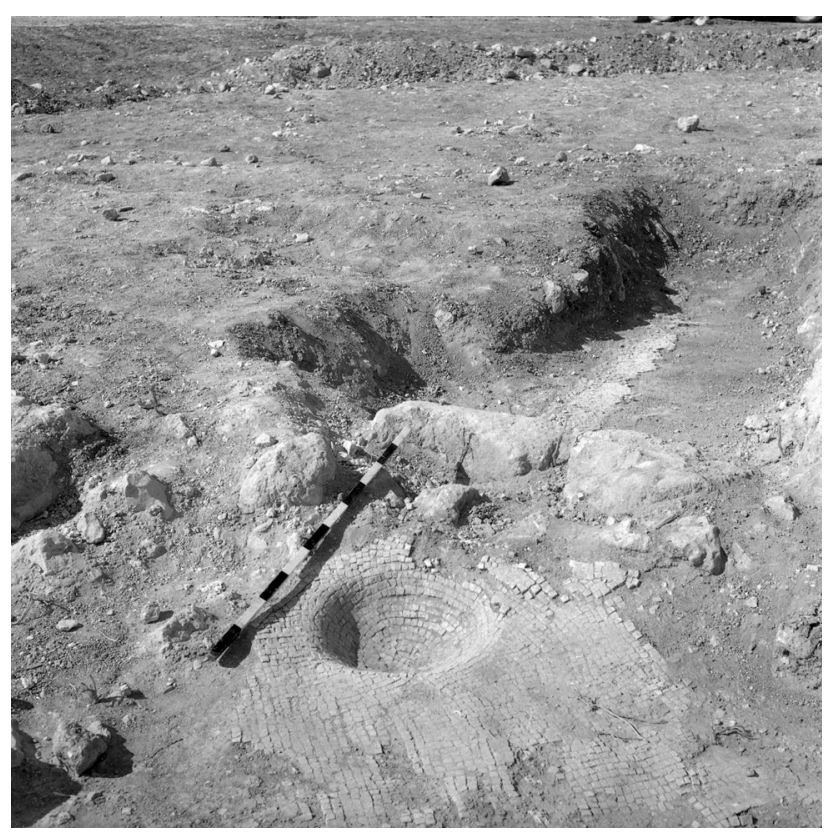

Fig. 15. The paved depression (photo: Israel Antiquities Authority Photo Archive; No. 23299) scales filled with florets also figure prominently both in the sixth-century and the Umayyad-period phases of the Kathisma Church, where the apse mosaic of the south-west chapel date to the former, while the apse mosaic of the northwestern chapel and the central panel of the north-west corner can be assigned to the latter period. ${ }^{33}$ The pavements in the inner southern aisle of the Basilica of the Nativity in Bethlehem $^{34}$ and in the narthex of the Khirbet 'Asida church ${ }^{35}$ have small squares within the scales instead of the usual florets, while on the $c a$. fifth-century, roughly contemporaneous intercolumnar mosaic in the Khirbet Jufra church ${ }^{36}$ scales appear without florets. Farther to the south, outlined scales with florets adorn the eastern half of the central mosaic panel in the monastery's chapel at Khirbat al-Qasr ${ }^{37}$ and the same pattern covers the sixth-century northern aisle mosaic of the

\footnotetext{
${ }^{33}$ Avner 2006-2007, 554, Fig. 3; Madder 2014, 47.

${ }^{34}$ Richmond 1936, Pl. XLVI; Ovadiah-Ovadiah 1987, 22, Pl. XVIII.

${ }^{35}$ BaramKI-Avi-YoNAH 1934, Pl. IX.

${ }^{36}$ Ovadiah-Ovadiah 1987, 124.

${ }^{37}$ Magen et al. 2012, 274, 276, Figs 44-45.
} 
Central Church at Bayt 'Aynūn, ${ }^{38}$ while along the shores of the Dead Sea, outlined scales with very schematic florets can be found among the decorative elements of the late fourth-to fifth-century mosaic pavements in the western aisle of the 'Ein Gedi synagogue. ${ }^{39}$ Moving in the opposite geographical direction, north of Jerusalem, and at the opposite end of the chronological range, a mosaic pavement with a floret pattern set into outlined scales also appears in the north-western aisle of the earlier eighth-century Jericho synagogue, which clearly attests to the long-standing acceptability of this decorative scheme in synagogue art. ${ }^{40}$ Yet, even in the latter city, this decoration is not restricted to synagogues, as indicated by a sixth-century pavement from the northern aisle of a church. ${ }^{41}$ Farther to the north-west, the north aisle of the Northern Church at Shiloh was paved with a mosaic embellished with outlined scales enclosing small leaves in the sixth century. ${ }^{42}$

In Church A at Magen in the western Negev, the western panels of the northern and the southern aisles, which were most probably created in two different phases, with one copying the other, also bear outlined scales with florets. ${ }^{43}$ Close to Magen, at Horvat Be'er Shema', the apse pavement of the church, believed to have been set during the last decades of the sixth century, is decorated with florets embedded in scales. ${ }^{44}$ Another church edifice in the Negev, the Western Church at Mampsis (in Palaestina Tertia), provides examples of the scale pattern, this time without florets, on the fifth-century intercolumnar mosaics. ${ }^{45}$ In the coastal area, a variant of our pattern decorated a portion of the narthex mosaic of a church in Ashkelon-Barne'a. ${ }^{46}$

Closer to our site, in Hazor-Ashdod, the early sixthcentury pavement in the southern aisle of a church building displays a scale pattern, ${ }^{47}$ while at Horbat Sokho, located approximately halfway between Khirbet el-Ras and Jerusalem, another ca. fifth-century pavement was discovered with outlined scales and florets in the northern room of what was tentatively identified as a church building. ${ }^{48}$ Outlined scales with florets likewise appear on the late fourth-to early fifth-century panel in the southwestern intercolumnation of the Samaritan synagogue discovered in Ramat Aviv. ${ }^{49}$ However, in geographical

\footnotetext{
${ }^{38}$ Magen 2012, 149, 151, Fig. 52, 154, Fig. 57.

${ }^{39}$ Ovadiah-Ovadiah 1987, 55-56, Pls Xliv.2, ClXXVII.2; Ovadiah 2011, 694, Fig. 4

${ }^{40}$ Baramki 1938, Pl. XX.2; Talgam 2014, 405-407, Fig. 489.

${ }^{41}$ Ovadiah-Ovadiah 1987, 143; Madden 2014, 81-82.

${ }^{42}$ Magen-Aharonovich 2012, 179-180, 183-185, 189, Figs 25, 30-32, 38

${ }^{43}$ Tzaferis 1985a, 2, Fig. 2, 10, Fig. 14; Tzaferis 1985b, 18-19, Figs 2-3.

${ }^{44}$ Gazit-Lender 1991, Pl. C.

${ }^{45}$ Ovadiah-Ovadiah 1987, 105.

${ }^{46}$ Ovadiah-Ovadiah 1987, 14, describing panels decorated with the J3 motif and florets, with Pls IV.2, V.1 perhaps illustrating these panels.

${ }^{47}$ Ovadiah-Ovadiah 1987, 68.

${ }^{48}$ Gudovitch 1996, 20*, Fig. 2.

${ }^{49}$ Ovadiah-Ovadiah 1987, 118, Pl. CXXXIV.1; Tal-TaXel 2015, 211-211, Fig. 1.3.2.
}

terms, the closest site with florets embedded in a scale pattern is Mazor. It is thus quite unfortunate that neither its date, nor the function of the site can be established with the necessary degree of certainty, ${ }^{50}$ not least because its rather slipshod quality also seems to match that of the Kefar Truman pavement.

Turning to the north, outlined scales with florets embellish the southern aisle of a church in Bahan. ${ }^{51}$ In Samaria, our motif appears in the eastern room of the annex building erected along the northern wall of a Byzantineperiod church in Abud. ${ }^{52}$ Two mosaic fragments, one with plain scales, the other with outlined scales, both with florets, associated with the original late antique church building were uncovered in the porch and the southern aisle of the medieval Church of Saint John the Baptist in Sebaste, ca. 40 $\mathrm{km}$ north-east of Khirbet el-Ras, ${ }^{53}$ while a further fragment came to light from the adjacent monastery. ${ }^{54}$

Farther to the north, scale mosaics with florets were discovered in Scythopolis/Bet She'an, the capital of Palaestina Secunda, both in Christian churches and in public edifices. To begin with the latter, a large earlier fifth-century (?) mosaic pavement embellished with a pattern of endlessly repeating plain scales with florets was discovered on the western covered portico of the Palladius street. ${ }^{55}$ The same pattern appears in Rooms 5 and 14 of the slightly earlier ( $c a$. 400) Nile Festival Building at Sepphoris. ${ }^{56}$ In contrast, Christian contexts from Bet She'an, such as the small niche south of the west door of the late fifth-to early sixth-century Round Church, ${ }^{57}$ the sixth-century aisle mosaics of a church at Tel Estaba and the pavement of its north-east chapel, ${ }^{58}$ and the central section of the mosaic panel of Room E as well as the apse mosaic of the monastery chapel of the mid-sixthcentury Monastery of Lady Mary ${ }^{59}$ provide evidence for the presence of florets enclosed by outlined scales. Immediately west-northwest of the city, scales with florets also embellish the sixth-century mosaic discovered in the south room of a chapel in Sede Nahum as well as the mosaic of 'Room 2' in the monastery excavated at Tell Bazul. ${ }^{60}$ East of Bet She'an, floral semis ornaments embedded in plain scales encircle a mosaic inscription dated to $482 \mathrm{CE}$ in a church building at Khirbat al-Maqāti', located ca. $6 \mathrm{~km}$ north of 'Ajlūn. ${ }^{61}$ Farther north-east, outlined scales cover the nave mosaic of a

\footnotetext{
${ }^{50}$ Ovadiah-Ovadiah 1987, 110.

${ }^{51}$ Ovadiah-Ovadiah 1987, 15, Pl. VI.1.

${ }^{52}$ TAHA 1997, 373, Pl. 20, Fig. 10.

${ }^{53}$ Crowfoot 1937, 29, Pl. 17b-c.

${ }^{54}$ MAdDEN 2014, 122.

${ }^{55}$ Tsafrir-Foerster 1997, 114, Fig. 24.

${ }^{56}$ Weiss-Talgam 2002, 86-89, Figs 19, 25.

${ }^{57}$ FitzGerald 1931, Fig. between pages 18 and 19; Avi-Yonah 1981, 290, No. 14.4 .

${ }^{58}$ Talgam 2014, 127 Fig. 178; Madden 2014, 165.

${ }^{59}$ FitzGerald 1939, Pls XII, XIV-XV.1; Braun 1985, 201, Pl. XLVIII.1-2.

${ }^{60}$ Ovadiah-Ovadiah 1987, 125, 138.

${ }^{61}$ VAN ELDEREN 1972.
} 
late fifth-to early sixth-century church at Hawfā al-Wastiyya, too, ${ }^{62}$ and appear on a nearly contemporaneous or slightly later pavement from Hayt. ${ }^{63}$ Still in Palaestina Secunda, but farther to the east, the nave and the aisles of the great fiveaisle basilica of al-Suwaydā' were paved in the late fifth or in the sixth century with florets enclosed in plain scales. ${ }^{64}$

The appearance of this pattern is also recorded in the opposite geographical direction, among the earlier, most probably fifth-century mosaics in the southern aisle of the Basilica of the Annunciation in Nazareth. ${ }^{65}$ It was likewise reported to have been used on the later sixth-century upper pavement in the apse of the South Chapel at Kafr Kama. $^{66}$

The same pattern recurs in the bema and the nave of a church building excavated at Khirbet Samra on the eastern shore of the Sea of Galilee. ${ }^{67}$ The late fifth-to early sixthcentury mosaics in the nave and later sixth-century pavement in the baptistery set up in the south-eastern room of the monastery church at Kursi/Gergesa bear plain scales with florets. ${ }^{68}$ Not far from Kursi, florets set in outlined scales decorate the large central panel of the sixth-century pavement of the northern aisle of the North-West Church at Hippos/Sussita, while in the southern aisle and the southern sacristy, floral semis embedded in plain scales cover the entire surfaces. ${ }^{69}$ The apse of the South-West Church is likewise embellished with florets enclosed in outlined scales, ${ }^{70}$ and the same motifs appear on the late sixth-century pavement in the baptistery of the South-East Church (the Cathedral). ${ }^{71}$

On the opposite side of the Sea of Galilee, plain scales appear in the eastern room of the northern wing of the church on Mount Berenike in Tiberias, ${ }^{72}$ while outlined scales can be found among the mosaics adorning the eastern aisle in the Lower Synagogue at Hammath Tiberias. ${ }^{73}$ As we have seen in the above, the latter pavement is hardly the single occurrence of this decorative system in synagogue art. Yet, churches remain the main contexts of our pattern. To the north of Tiberias, at Migdal/Magdala, 'Room 17' of a Byzantine-period monastery was paved with plain scales enclosing florets, ${ }^{74}$ while halfway between Tiberias and Khirbet Samra, at Khirbat al-Karak (Bet Yerah), the main sanctuary area and both pastophoria were paved with mosaics of this type in both

${ }^{62}$ Michel 2001, 133-135, Fig. 81.

${ }^{63}$ Doncel-Voute 1988, 122-123, Fig. 84.

${ }^{64}$ Doncel-Voûte 1988, 309-312, Fig. 303.

${ }^{65}$ BagatTi 1969, 103-104, Fig. 58.

${ }^{66}$ Ovadiah-Ovadiah 1987, 87.

${ }^{67}$ Tzaferis 1993, 237, Fig. 10; Madden 2014, 160.

${ }^{68}$ Tzaferis 1983, 26; DonCel-Voûte 1988, 169-172, Fig. 142.

${ }^{69}$ MeynarczyK-Burdajewicz 2005, 42-44, Figs 3D, 4A; Burdajewicz 2017, 515-516, 522, Figs 3, 5, 10.

${ }^{70}$ Segal et al. 2005, 20, Figs 7, 43-44.

${ }^{71}$ Ovadiah-Ovadiah 1987, 136.

${ }^{72}$ Hirschfeld 2004, 137, Fig. 8.5.

${ }^{73}$ Ovadiah-Ovadiah 1987, 65, Pl. LXV.1; Hirschfeld 2005, 9.

${ }^{74}$ Corbo 1974, 14, Figs 5, 17; Ovadiah-Ovadiah 1987, 111, Pl. CXXIV.2. sixth-century phases of the church. ${ }^{75}$ At the opposite, northern side of the lake, outlined scales fill the central space of the fifthcentury Octagon at Capernaum ${ }^{76}$ and they reappear in the mosaic panels of the bema and the northern nave in the fifthcentury mosaics of the Church of the Multiplication at nearby Tabgha. ${ }^{77}$ In the latter village, plain scales with florets decorated a mosaic panel in the hall of the chapel of the monastery erected on the 'Mount of Beatitudes.' ${ }^{78}$

Sites in western Galilee can also be mentioned, which brings us to the eastern border region and south-eastern end of the province of Phoenicia Maritima. To name but a few, let us refer to the plain scales and their florets covering the nave of the church at Horbat Medav, ${ }^{79}$ the ones in the intercolumnar spaces of the earlier sixth-century church at Horbat Hesheq, ${ }^{80}$ and the same design in the south-eastern annex room of the somewhat later church at Kirbet el-Ghureiyib. ${ }^{81}$ Beside church edifices, the same design was also employed in domestic contexts in the region, as the recently published seventh-century mosaic floor discovered at Pi Mazuva demonstrates. ${ }^{82}$ Florets set into outlined scales are displayed in the mid-sixth-century southern aisle of the Khirbet Bata church, ${ }^{83}$ on the mosaics set adjacent to the narthex pavement of the sixth-century church at Horbat Kenes ${ }^{84}$ and on the later eighth-century pavement of the northern aisle in a church at Khirbet el-Shubeika. ${ }^{85}$

On the coast, in the province of Phoenicia Maritima, in Shavei Zion, the entire early fifth-century pavement of the nave of a church is covered with florets integrated into plain scales. Another mosaic panel decorated with florets, this time enclosed in outlined scales, appears among the decorative elements of the later fifth-century pavement of the north-eastern chapel of the same church. ${ }^{86}$ A comparable design can be found in Nahariya, immediately north of Shavei Zion, where plain scales with florets grace both the nave and the two aisles of the probably earlier sixth-century pavements in the church, and the same pattern adorns the fragment of a pavement set in 'Room 1' of the building attached to the southern wall of the church edifice. ${ }^{87}$ In the neighbouring settlement of Evron, the late fifth-century

\footnotetext{
${ }^{75}$ Delougaz-Hanies $1960,13-14$, 21, Pls 24-25; Ovadiah-Ovadiah 1987, 43.

${ }^{76}$ LOFFrEDA 1985, 64; LOFFREDA 2005, 82.

${ }^{77}$ SChNeider 1937; Bagatti 1971, 204, Fig. 71.

${ }^{78}$ Bagatti 2001, 72-73, Fig. 37; Ovadiah-Ovadiah 1987, 57, Pl. XLV.

${ }^{79}$ Aviam 2002, 207-208, Figs 101, 103.

${ }^{80}$ Aviam 2002, 180 Fig. 20.

${ }^{81}$ Aviam 2002, 199, 201 Fig. 58.

${ }^{82}$ Talgam 2020, 58*, Fig. 1.

${ }^{83}$ Yeivin 1992, 118-119, Fig. 18.

${ }^{84}$ Aviam 2004, 189, Fig. 17.13.

${ }^{85}$ SYON 2002, 260.

${ }^{86}$ Avi-YonaH 1967, 48, 60-61, Fig. 7, Pls VIIb, X-XI, XIIIb, XXXVIIIb, XLIb.

${ }^{87}$ Dauphin-Edelstein 1984, 44-50, Pls VII, IX, XI.
} 
mosaic of the narthex bears plain scales with florets, too. ${ }^{88}$ Florets embedded into plain scales dominate among the Tel Shiqmona mosaics, where pavements decorated with this pattern can be counted among the very popular ones. ${ }^{89}$ Close to Tel Shiqmona, at Kiryat Ata, outlined scales with florets covered the sixth-century mosaic of the nave. ${ }^{90}$

To the north, in Dayr al-Zahrān̄, south of Sidon, florets inscribed in plain scales appear on the earlier sixth-century narthex mosaic, ${ }^{91}$ and in all likelihood the same pattern adorned the later sixth-century pavement covering the entire interior of a church building at Nabī Yūnus, north of Sidon. ${ }^{92}$ The same pattern was also documented on the midsixth-century nave mosaic of the Upper Church at Khān Khalda, south of Beirut, ${ }^{93}$ while in Beirut itself, florets inscribed in plain scales decorate a mosaic pavement discovered in a villa building dated roughly to the fifth-sixth centuries. $^{94}$

As we have seen in the above, the predominance of florets inscribed in plain scales characterizing the churches of Phoenicia Maritima is not universal elsewhere. The same holds true for the Syrian provinces, too, where a more even distribution of the plain and the outlined variants can be noted. In the northern regions of Syria Prima, the later fourth- or perhaps fifth-century mosaic panel in the southern annex room of the eastern nave of the suburban martyrion of Saint Babylas at Antioch ${ }^{95}$ displays the outlined versions, while a predilection for the plain variant can be noted among the possibly earlier sixth-century pavements of the nave and both aisles of the Machouka church, located outside the walls of Antioch. ${ }^{96}$ Additionally, mention can be made of a pattern made up of outlined scale motifs without florets on the mid-fifth-century mosaics of the martyrion of the Church of Julianos at Brād. ${ }^{97}$ Yet, a cautionary remark is also in order as to the frequency of florets with plain scales, because in household contexts at Antioch, which constitute the major source of our knowledge of Roman to late antique mosaic production in Syria Prima, the predominance of plain scales is more than evident. (See, e.g., the earlier-to mid-fifthcentury small apse in the House of the Buffet-Supper, ${ }^{98}$ the famous fifth-century phoenix mosaic, ${ }^{99}$ the later fifth- or early sixth-century pavement set in an apse of the later phase of the

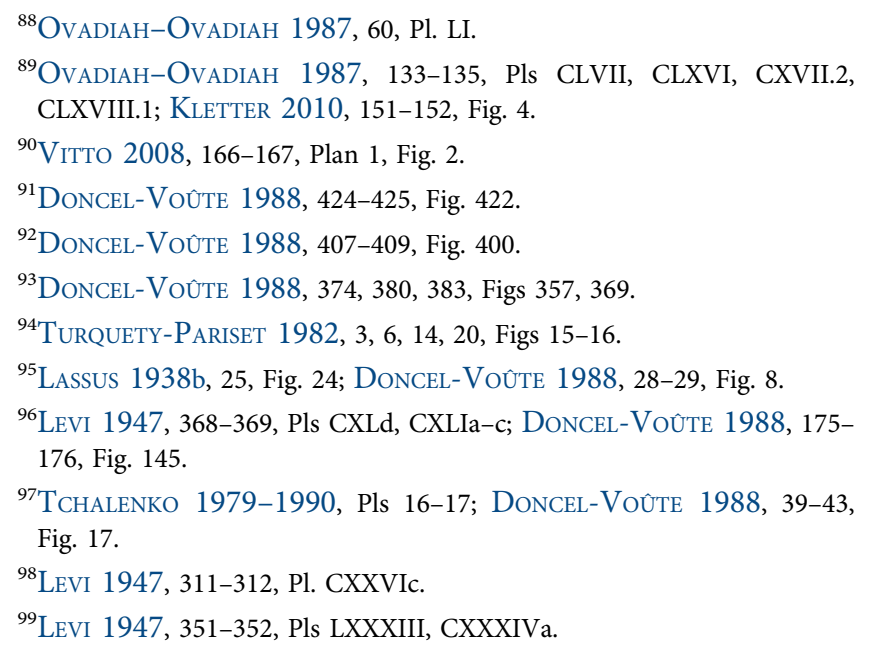

House of Aion, ${ }^{100}$ and the earlier sixth-century mosaic in the centre of a room in the House of the Bird-Rinceau. ${ }^{101}$

In contrast, the exact opposite can be said of the mosaic floors of late antique churches on Cyprus, where outlined scales were the preferred type, ${ }^{102}$ which also appear on Crete. ${ }^{103}$ In more western provinces of the Later Roman Empire, the use of scale patterns filled with the floral semis was rather limited. ${ }^{104}$ Instead, as an unbroken continuation of earlier Roman tradition, ${ }^{105}$ polychromatic scales were preferred both in ecclesiastic and profane contexts. ${ }^{106}$ The above-described tendencies are copiously attested in the archaeological record of late antique Anatolia, too. Here, in the regions closer to the Syrian provinces, plain scales constituting the background to animal imagery are frequently documented, as at Edessa/Şanliurfa in Oshroene, ${ }^{107}$ Germanicia Caesarea/Kahramanmaraş ${ }^{108}$ and Korucak Köy ${ }^{109}$ in Euphratensis, near Alimpinar in Armenia Secunda, ${ }^{110}$ and in Cappadocian Parnassus. ${ }^{111}$ Outlined scales enclosing florets $^{112}$ and triangles ${ }^{113}$ are also documented both in these regions and slightly farther to the west, e.g. at Eleaiussa Sebaste in Cilicia Prima. ${ }^{114}$ In the more western provinces, however, the use of polychromatic scales is hardly unusual, as at Tlos in south-western Anatolian Lycia. ${ }^{115}$

In the province of Arabia, outlined scales enclosing florets seem to appear only slightly later in the currently known mosaic record than in the two Palaestinae and they play a more restricted role in mosaic decoration. This pattern occurs relatively rarely on its own covering larger surfaces. On a late sixth-century pavement in the Church of Saint Basil at

\footnotetext{
${ }^{100}$ LeVi 1947, 355-356, Pl. LXXXIVc.

${ }^{101}$ LeVi 1947, 366, Pl. XC.

${ }^{102}$ DaszewsKi-Michaelides 1988, 128-134, Figs 54-58.

${ }^{103}$ Farioli Campanati 2009, 688, Fig. 7.

${ }^{104}$ Negrelli 2018, 283-284, Fig. 3; cf. DaszewsKi-Michaelides 1988 , 132. See also the earlier sixth-century mosaic covering one of the vaults of the southern triumphal arch in the presbytery of the Basilica of San Vitale, Ravenna. It combines polychrome outlined scales and florets. Unfortunately, this detail can be barely made out in the photo published in Deichmann 1958, Pl. 312 (the mosaic is set on the right-side vault, on the same level as the kantharos situated above the image of the lion symbolizing the evangelist Mark).

${ }^{105}$ Cf. Swith 2019, 57-65.

${ }^{106}$ E.g. Blanchard-LemÉe 1975, Pl. XLVI; Aleksova 1997, 375, Fig. 94; CekA-Muçaj 2005, 45, Fig. 35, 79, Fig. 62b; Hoddinott 1963, Pl. 41b; Maltoni et al. 2008, 32, Fig. 18; Blanchard-LemÉe 2019, 180, Fig. 143.

${ }^{107}$ YAVUZKIR 2016, 231, 233-234, Figs. 8, 13-14.

${ }^{108}$ DenizhanoĞUllari et al. 2018, 8-9, Figs 5-6.

${ }^{109}$ YilmaZ-Fistikçı 2015, 229, 230-231, Figs 5, 8-10.

${ }^{110}$ DenizhanoĞUllari-Güriçin-ǗNLÜ 2018, 199, Fig. 6.

${ }^{111}$ ArsLan et al. 2011, 203, 205-207, Figs 3, 6-10.

${ }^{112}$ Edessa: YavUZKir 2016, 230, 233-234, Figs 5, 11, 14.

${ }^{113}$ Düziçi: TÜrkmenoĞLU et al. 2018, 33, Fig. 4; Olukluçunur Köyü: NALÂN et al. 2016, 661, Fig. 1.

${ }^{114}$ Mosaic of the 'Small Baths' with florets: EQUINI SCHNEIDER 2015, 490, Fig. 11.

${ }^{115}$ Urano-Fukatsu-YÜCel 2016, 412, 420, Fig. 7.
} 
Rìhāb, the apsidal area displays this pattern, ${ }^{116}$ while in the Memorial of Moses on Mount Nebo, the earlier sixth-century $\mathrm{U}$-shaped pavement around the baptismal font is covered by it. ${ }^{117}$ The same can be seen in the western ends of both the northern and the southern aisles of the Church of Saint Peter at Khirbat al-Samrā', paved in the earlier sixth century. ${ }^{118}$ An even smaller surface was allotted to the outlined scales, in this particular case without enclosed florets, decorating a narrow mosaic strip set along the north-western wall of the northern aisle of the eighth-century Church of Saint Stephen in Umm al-Rasās.. ${ }^{119}$ An only slightly larger area was decorated with outlined scales in one of the intercolumnar spaces separating the nave from the northern aisle in the later sixthcentury Church of Bishop Sergius, adjacent to the former edifice. $^{120}$ Similarly, one of the intercolumnar spaces, this time between the columns separating the nave and the southern aisle, was embellished with outlined scales in the sixth-century Church of Procopios in Geresa. ${ }^{121}$ In the later sixth-century chapel at Khirbat al-Muniyya, some $6 \mathrm{~km}$ north of Geresa, only the pavement of the entrance leading from the narthex to the nave bears this ornament. ${ }^{122}$

In the foregoing, the widespread popularity of the floral semis ornament embedded in plain or outlined scales was demonstrated, and the same holds particularly true for the decorative elements used in other parts of the Kefar Truman pavements. A quick look at the extensive mosaic corpus of the Roman and late antique Mediterranean demonstrates the extreme popularity of simple lozenges, simple guilloche ornaments, and the rhythmically set triangles both as selfcontained ornaments and, in the case of the latter two, their frequent combination, as in the central panel's tripartite frame on the Khirbet el-Ras pavement. ${ }^{123}$ Unfortunately, given the long use and widespread popularity of these ornaments, they cannot provide a good chronological anchor for dating our mosaic. Yet, it is perhaps not a futile exercise to name a few examples where a simple guilloche (Caesarea Maritima, ${ }^{124}$ Kiryat Ata, ${ }^{125}$ Hippos/Susita, ${ }^{126}$ Bethlehem, the Basilica of the Nativity, scales filled with squares ${ }^{127}$ ), a row

\footnotetext{
${ }^{116}$ Piccirillo 1997, 311, Fig. 626.

${ }^{117}$ Piccirillo 1986, 77-78, Figs 67-68; Piccirillo 1997, 146-147, Figs 182, 184; PicCirillo 1998, 273-275, Figs 12-15.

${ }^{118}$ Piccirillo 1997, 307, Figs 606, 608; Michel 2001, 202-205, Fig. 172, DesreumauX-Humbert 2003, 27, Fig. 7.

${ }^{119}$ Piccirillo 1994, Plan II, 135, Fig. 23, 152, Fig. 45; Piccirillo 1997 , 238-239, Fig. 383.

${ }^{120}$ Piccirillo 1994, 121, Figs 2-3, Plan II; Piccirillo 1997, 234-235, Fig. 365; Michel 2001, 384-387, Fig. 361.

${ }^{121}$ Biebel 1938, 338, Pl. LXXX/H; Michel 2001, 241-245, Fig. 221.

${ }^{122}$ Piccirillo 1997, 299, Fig. 288; Michel 2001, 275-278, Fig. 264.

${ }^{123}$ Cf. Avi-Yonah 1981; Ovadiah-Ovadiah 1987; Talgam 2014, 120.

${ }^{124}$ PATrich 2011, Fig. 75.

${ }^{125}$ ViтTO 2008, Fig. 2.

${ }^{126}$ MeynarcZiK-Burdajewicz 2005; Burdajewicz 2017; SEgal et al. 2005.

${ }^{127}$ RichmOND 1936, Pl. XLVI.
}

of triangles (Tiberias, Mount Berenike ${ }^{128}$ ) or their combination (Jerusalem, Mount Zion, ${ }^{129}$ Khān Khalda, scales filled with florets and squares ${ }^{130}$ ) frame a scale pattern.

Two distinctive traits of our pavements among the period's monuments are the lack of figural scenes, even though this was hardly unknown in the period's mosaic art, ${ }^{131}$ and the internal arrangement of the otherwise oft-recurring decorative schemes within the church space. As to the former, the need for due caution must be emphasized in view of the complete loss of the sanctuary mosaic. As other examples clearly demonstrate, a minimal figural decoration was sometimes introduced even into overwhelmingly aniconic decorative schemes. To mention but a few telling examples, let us refer here to the pavements discovered at Khirbet Samra ${ }^{132}$ and the one known from Khirbet Beit Sila. ${ }^{133}$ While fully aware of the above constraint, the use of an exclusively aniconic decoration both in the central and the side spaces does not seem to be a particularly common choice in the period's church art in the southern Levant. Yet, completely preserved sets of pavements characterized by a rich array of decorative patterns and a high quality of workmanship, like the ones excavated in the Northern Church of the Herodion ${ }^{134}$ and in the Western Church at alYasila, ${ }^{135}$ to name but a few sites, underline that neither the appearance of church pavements made up exclusively of aniconic decorative elements is entirely surprising, nor can they be ascribed to limited funds of the pavements' patrons or the lack of the appropriate artistic skills of their craftsmen.

The latter observation takes us to our second point. As noted in the above, the mediocre quality of the Kefar Truman mosaics is indicated by several features. Although it is hardly unusual for geometric pavements to be normally set with larger tesserae and to employ a more limited array of colours than in the case of figural ones, ${ }^{136}$ the use of fairly large and irregularly-cut mosaic stones for the Kefar Truman pavements cannot merely be explained by this practice. In the spots where the density of tesserae is the highest, namely the inscribed panel and the tripartite frame of the central panel (Figs 7, 10 and 11), it varies between 55 and 65 stones per square decimetre, while in the central field of the central panel it rarely exceeds the 40 and 50 stones per sq. $\mathrm{dm}$. The slight, but well-discernible variance in the sizes of the unevenly spaced scales points as much in the same direction as does the use of a limited number of colours (four) ${ }^{137}$

\footnotetext{
${ }^{128}$ HirschFeld 2004, 137, Fig. 8.5.

${ }^{129}$ Kenyon 1967, PL. XVIII; Tsuningham 1985, Pl. 72; OvadiahOVADIAH 1987, 83, Pl. XCV.

${ }^{130}$ Doncel-Voûte 1988, 378, Fig. 364.

${ }^{131}$ Cf. Talgam 2014, 104-107.

${ }^{132}$ Tzaferis 1993.

${ }^{133}$ Talgam 2014, 203, 205, Fig. 293.

${ }^{134}$ NetZer 1990, Netzer-Calderon-Feller 1993.

${ }^{135}$ Nassar-AL-MuHeisen 2010.

${ }^{136}$ Cf., e.g., Weiss-Talgam 2002, 90

${ }^{137}$ Cf. Talgam 2014, 175.
} 
and the placement of the lozenges against a plain white background without the slightest effort to employ an ornamental element that would merge them into a unified pattern. Taken together, one can hardly escape the impression that in this particular case, a monastic community with rather limited financial means hired a workshop of secondary importance. Whether this state of affairs played any role in that they opted for an entirely geometric design, or whether this choice was rather influenced by the views of the community commissioning the mosaic as to what can be considered as appropriate and acceptable for decorating sacred spaces, is more difficult to tell. What is quite certain, however, is that their choice of adorning the entire nave with florets enclosed by outlined scales was a fairly uncommon solution. A quick look at the above list of the use of florets inscribed in scales reveals that in the majority of the known instances, this pattern was employed in side aisles, intercolumnar spaces, narthexes, baptisteries, and other less prominent spaces rather than in naves. In a sense, this is clearly a continuation of the age-old Roman habit of employing the scale pattern in marginal and auxiliary spaces. ${ }^{138}$ When we do encounter this pattern in naves, some regional factors seem to be in play. The appearance of the plain variant in the fifth-to mid-sixth-century churches in Phoenicia Maritima (Horbat Medav, Khān Khalda, Nahariya, Nabī Yūnus, Shavei Zion, Tel Shiqmona, alongside the outlined variant at Kiryat Ata) is one obvious regional trend, while the preference for the outlined variant in the sixth century east of the Sea of Galilee (Hawfā al-Wastiyya, Khirbet Samra, al-Suwaydā') might indicate another. The main difference between the plain and the outlined versions may be sought in their possible symbolic associations. In the case of the florets set against plain scales, it is not at all unimaginable that for the late antique beholder, the pattern in question evoked an association of a natural landscape, which, in view of the paradisiacal connotations of certain church spaces, would make it an ideal choice for covering central liturgical spaces. On the other hand, the outlined version with its strongly articulated geometric design would be less likely to conjure up such a direct association and was thus better suited as a space-filler rather than a bearer of some symbolic meaning. However, even in these cases it cannot be excluded that outlined scale patterns played a certain function beyond mere decoration. As simple scale patterns were often employed in Roman mosaic design to direct the beholders' view and attention toward certain directions, ${ }^{139}$ the same role could have been fulfilled by mosaic floors covered by outlined scales filled with florets. It is thus perhaps no coincidence that in the Kefar Truman church's nave the scale pattern was set to direct the visitors' gaze from the entrance area towards the sanctuary, and not in the opposite direction. The lack of an explicit and unequivocal symbolism is perhaps one of the reasons why patterns made up of outline scales were considered as being appropriate for decorating the central spaces of

\footnotetext{
${ }^{138}$ For this tradition, see the illuminating discussion in SWIFT 2019, 57-65, 68-70.

${ }^{139}$ Cf. SwITH 2019, 58-60, 65.
}

both churches, synagogues, and private buildings in the Umayyad period, as shown by the examples of the Khirbet elShubeika church, the Jericho synagogue, and Walid II's bathhouse at Khirbet el-Mafjar. ${ }^{140}$ In any case, given the polysemantic nature of ornaments, their interpretation is largely open-ended and thus their occurrences in diverse contexts offer different potential readings. Thus, the appearance of outlined scales filled with florets in a fresco discovered on the narthex wall of an early Christian basilica at Eleutherna $(\text { Crete })^{141}$ can be read in at least two different ways, either as "mere ornament" applied with the aim of beautification, or as a visual allusion to a natural landscape symbolized by the florets, which the beholder can admire through an openwork parapet wall denoted by the scale imbrication pattern (a reading hardly conceivable in the case of floors).

\section{The inscription}

Five-line Greek inscription written in round letters, set in a tabula ansata $(0.93 \times 1.42 \mathrm{~m}$; Fig. 10). It was found almost intact, only the last fourth of the lower three lines are lost and two shorter sections of lines 1 and 2 are damaged. Despite these losses, the inscription is wholly legible. It was written in black tesserae against a white ground:

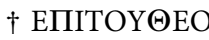

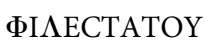

\section{ПРЕCВsКЕНГОМ}

\section{ENOYEYCEBIOY ...}

\section{NE $\Theta \Theta H O N A$. .}

$\dagger \mathrm{E} \pi \mathrm{i} \tau \mathrm{ov} \theta \varepsilon \mathrm{o}^{-}$

$\varphi \perp \lambda \varepsilon \sigma \tau \alpha \dot{\alpha} \tau o v$

$\pi \rho \varepsilon \sigma \beta(v \tau \dot{\varepsilon} \rho o v) \kappa \dot{\varepsilon} \dot{\eta} \gamma o(v) \mu-$

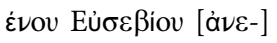

$\nu \varepsilon \dot{\omega} \theta \eta$ ò $\nu \alpha[o ́ s]$

" $\dagger$ In the time of the most god-loving priest and the abbot Eusebius the nave was renewed."

Based on palaeographic considerations, Leah di Segni suggested a date in the third quarter of the fifth century for the inscription. ${ }^{142}$

\section{The finds}

Pottery. According to the original field report, a number of pottery sherds, oil lamps, and glass finds were collected during the excavation. Unfortunately, none of these objects were available for study at the time we attempted to locate them.

\footnotetext{
${ }^{140}$ Hamilton 1959, Pl. LXXII.

${ }^{141}$ Themelis 2004, 49, 82, Fig. 27a-b.

${ }^{142} \mathrm{We}$ are particularly grateful to Leah di Segni for translating the inscription and her suggestion for the date.
} 
Metal finds. Two of the three metal small finds currently available for study from among the ones discovered in 1958 clearly postdate both the church's construction phase and the building's use for Christian religious purposes. The copperalloy fragment decorated with a continuous tendril ornament (Fig. 16.3) seems to be of medieval or post-medieval date, while the iron horse-shoe (Fig. 16.4) is a modern artefact. ${ }^{143}$ The small copper-alloy ring bent from a simple wire (Fig. 16.5) represents a very common form and therefore cannot be precisely dated merely on typological grounds.

\section{Coins by Gabriela Bijovsky}

Four coins were discovered during the excavations at the church in Kfar Truman. ${ }^{144}$ Unfortunately, the identification cards lack locus and basket information. All coins are folles made of copper. The earliest coin belongs most likely to Justinian I's undated series (527-538 CE) (No. 1). This is followed by two folles of Maurice Tiberius minted in Nicomedia. One is clearly dated to 599/600 CE (No. 2), while the other follis bears an illegible date (No. 3). The latest coin is an Arab-Byzantine overstruck imitation (No. 4). This series is roughly dated to the years $647-670 \mathrm{CE}$ and was most probably minted in jund Filastin.

\section{Catalogue}

1. IAA 4493

Justinian I (527-565 CE), 527-538 CE, Nicomedia.

Obv: [DNIVSTINI]ANVS PP AVG Bust r., diademed, cuirassed and draped.

Rev: $\mathbf{M}$ above cross; to r. cross; other details are illegible. Copper, Follis, 8, 12.61g, $29 \mathrm{~mm}$.

DOC I, 78-79, No. 28.

2. IAA 4495 (Fig. 16.1)

Maurice Tiberius (582-602 CE), 599/600 CE, Nicomedia. Obv: [d]mTIbER ImAVRPPA Bust facing, wearing crown, holding globe with cross and shield, cuirassed and draped. Rev: $\mathbf{M}$ to 1.: ANNO; above cross; to r. date: X/ЧI/II; below: A; in ex.: NIKO

Copper, Follis, 7, 11.23g, $30 \mathrm{~mm}$.

DOC I, 327, No. 107.

3. IAA 4494

Maurice Tiberius (582-602 CE), illegible date, Nicomedia. Obv: [-] Bust facing, wearing crown, holding globe with cross and shield, cuirassed and draped. Rev: $\mathbf{M}$ to 1. : ANNO; above cross; to r. illegible date; below: A; in ex.: NIKO

Copper, Follis, 7, 9.92g, $28 \times 31 \mathrm{~mm}$.

Cf. DOC I, 323-327, Nos 91-108.

4. IAA 4496 (Fig. 16.2)

Arab-Byzantine I imitation, ca. 647-670 CE, jund Filastin.

\footnotetext{
${ }^{143}$ Cf. Khamis 2010, 283-284, Photos 12.2-3.

${ }^{144}$ The coins were cleaned at the IAA laboratories under the direction of Ella Altmark, and photographed by Clara Amit of the IAA. The coins were first identified by Helena Sokolov of the IAA coin department.
}

Obv: Imperial figure standing facing, holding a globe with cross and a long cross.

Rev: $\underline{\mathbf{m}}$; to $1 .: \mathrm{I}$

Copper, follis, 6, overstruck, 2.63g, $24 \mathrm{~mm}$.

Cf. SICA I, group E.

\section{CONCLUSIONS}

\section{Date}

Based on the above data, it is not particularly easy either to ascribe a precise date to the church's construction phase or to reconstruct the site's later occupation history, not least because purely geometric mosaic pavements are notoriously difficult to date on their own. ${ }^{145}$ Given the closer and more distant parallels of the central pavement reviewed briefly in the above, a mid-fifth- to mid-sixth-century date could be proposed for the mosaic floor as a fair approximation. Yet, a cautionary note seems in order. Although it has been widely assumed for a long time that strongly stylized florets set into outlined scales, as seen on the Kefar Truman mosaic, should rather be dated to the sixth century, based mainly on the stylistic and chronological development of the mosaic pavements of Antioch, ${ }^{146}$ a slightly more cautious approach is necessary. Even if the prevalence of plain scales among the Levantine pavements of the fifth century is still detectable (as rightly observed by F. Vitto ${ }^{147}$ ), outlined scales also appear on mosaics dated to the latter part of that century (see, for example, the church on Mount Zion and the Northern Church of the Herodion $^{148}$ ). Without recapitulating here the diverging views on the origins and eastern connections of the structured semis decoration, ${ }^{149}$ we would highlight a single point. The appearance of the elaborately-crafted florets embedded into outlined scales on the apsidal mosaic in the domina's apartment at Piazza Armerina, ${ }^{150}$ set in the 320 s-330s most probably by a North African workshop, duly explains how florets reflecting widely different levels of schematization appear at different sites already at the end of the fourth and the beginning of the fifth centuries. ${ }^{151}$ While the pavements of the Nile Festival Building at Sepphoris, dated to ca. 400, display more schematized florets than the somewhat later Phoenix mosaic at Antioch, the stylization of the florets of

\footnotetext{
${ }^{145}$ Cf. TAlgam 2014, 169.

${ }^{146}$ DAsZEWSKI-MiCHAelides 1988; and with differences: DONCELVOÛTE 1988, 456-457; VITTO 2008.

${ }^{147}$ ViтTо 2008, 167.

${ }^{148}$ Netzer 1990; Netzer et al. 1993; Ovadiah-Ovadiah 1987, 83, Pl. XCV.

${ }^{149}$ See LASSUS 1938a, 96-104, 119-120; LAVIN 1963, 196-198; DONCELVoûte 1988, 456; Gonosová 1987.

${ }^{150}$ Carandini-Ricci-De Vos 1982, 239-243, Fig. 142, Pl. XXXV.

${ }^{151}$ For the role of decorative schemes of North African mosaics in the development of the period's Levantine mosaic art, cf., e.g., TALGAM 2014, 85-97, 128.
} 

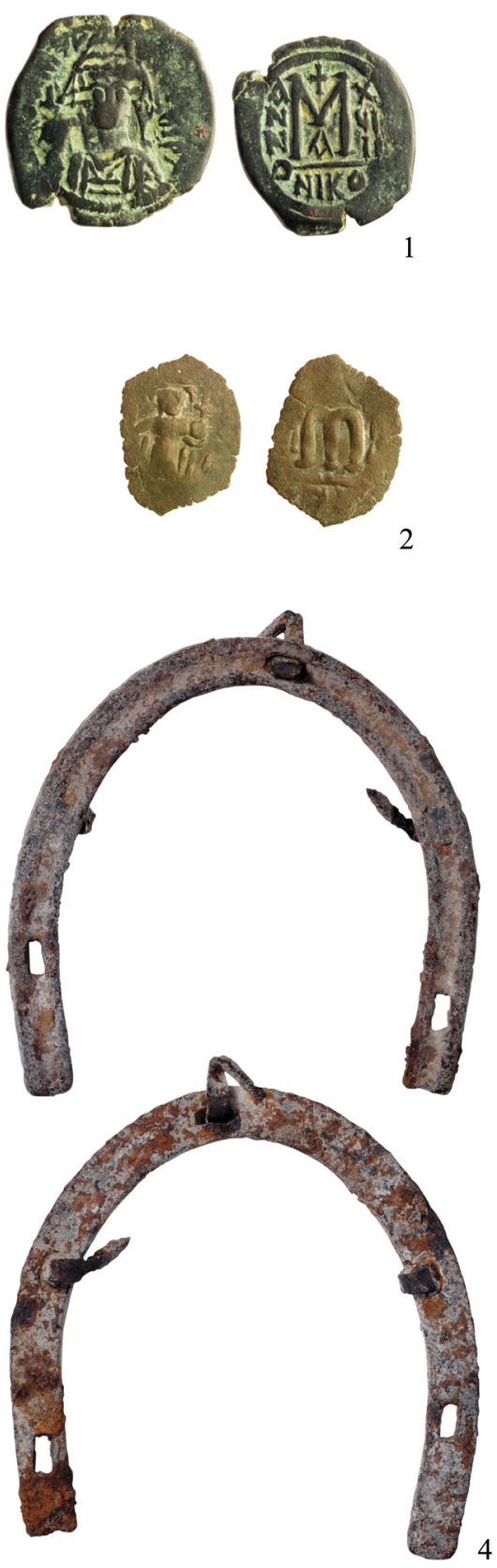

4 the 'Ein Gedi synagogue mosaic, dated to the later fourth to fifth centuries, shows a very advanced stage. The differences between the stages of stylization of the florets on the mosaic of the late fourth-/early fifth-century synagogue in Ramat Aviv, the early fifth-century pavement of Shavei Zion, the mid-to later fifth-century mosaic panel of the Herodion thus seem to depend as much on the quality of their workmanship as on their respective dates. It is therefore hardly surprising if florets representing more or less the same level of stylization do appear on a large number of pavements between the fifth and eighth centuries. ${ }^{152}$

${ }^{152}$ Cf. Doncel-Voúte 1988, 457.
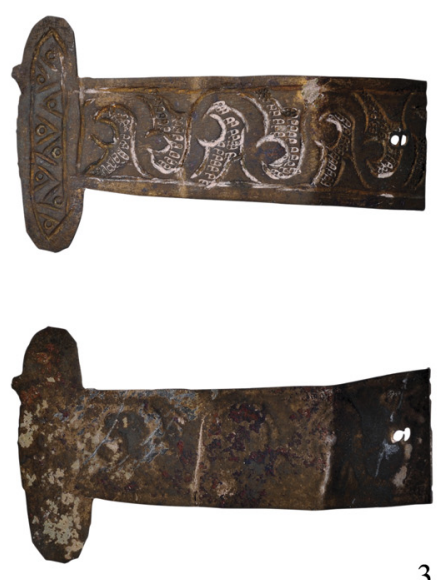

3
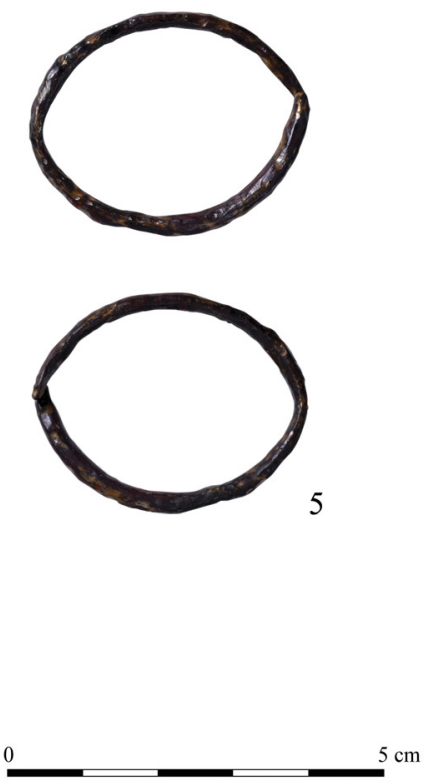

It is also true, though, that more elegantly crafted semis ornaments rarely occur after the late fifth century, while the truly elaborately-crafted floret depictions rich in details, as the ones displayed on the church floor at the Cappadocian Parnassos, dated by its inscription to 469-470 CE, are currently among the exceptionally rare occurrences of that time. ${ }^{153}$

Since based on palaeographic considerations the inscription should be ascribed to the third quarter of the fifth century or possibly earlier, a later fifth-century date can be proposed for the Kefar Truman pavement. Neither does this date

${ }^{153}$ ArsLAn et al. 2011, 196, 202-203, 205-207, Drawing 2, Figs 3, 6-11. 
contradict the (largely?) aniconic nature of the mosaic floor and the use of tesserae. ${ }^{154}$

On the testimony of the nave's mosaic inscription, it is also clear that the church was rebuilt or renovated at least once during its existence. It likewise seems reasonable to assume that the northern and southern wings are later additions to the main church building, which might have occurred at the same time, but in the lack of any obvious stratigraphic indications, it could have happened earlier or later, too. In view of the inscription's reference to renovation work undertaken in the church, there is good reason to assume that only the mosaic floor(s) was/were laid at that time, while the church building itself was built earlier, perhaps at the beginning of the fifth century, although a fourth century date cannot be entirely excluded in the lack of the necessary evidence. The stylistic date of the existing mosaic floors would not contradict this hypothesis.

Regrettably, neither the excavated coins, nor the pottery and other small finds are of any help in ascribing a more precise date to the phases of the monastery's foundation and its subsequent renovation mentioned in the mosaic inscription. What they do indicate is that the site was in use, perhaps continuously, through the Byzantine and at the beginning of the early Islamic periods.

\section{Function of the excavated remains and the place of the monastic church in the network of monastic institutions in the wider region}

In her original brief report, V. Sussman suggested that the excavated archaeological remains can be identified as those of a monastery. ${ }^{155}$ Her suggestion was accepted by later scholars, albeit with reservations for not being provided with the necessary details as regards the rationale underlying this interpretation. ${ }^{156}$ In view of the abovereviewed evidence, the identification as a monastic site seems possible, especially in view of Eusebius's title (hygoumenos) given by the inscription. The annex built against the main church edifice as well as the presence of a winepress and a cistern in the excavated area next to the church complex may also be seen as pointing toward a monastic complex. ${ }^{157}$

The church at Kefar Truman is located near a main junction of roads leading from the coastal plain to Jerusalem. Thus, it could have been part of the network of monasteries that were established along the main roads to serve pilgrims during the Byzantine period. ${ }^{158}$ Due to its strategic location, it may have continued to serve as a residential building or a farmhouse in later times, sometime after the beginning of the Islamic period.

\footnotetext{
${ }^{154}$ Cf. Talgam 2014, 131, 176.

${ }^{155}$ ZviLICHOVSKY 1960.

${ }^{156}$ BagatTi 2002, 211; SCHICK 1995, 364.

${ }^{157}$ Cf. Ashrenazi-Aviam 2014, 162.

${ }^{158}$ See Dayan 2015, Map 6.
}

\section{REFERENCES}

\section{Abbreviations}

DOS 1: Bellinger, A. R.: Catalogue of the Byzantine Coins in the Dumbarton Oaks Collection and in the Whittemore Collection. 1.: Anastasius I to Maurice. Washington D.C 1966, 491-602.

SICA 1: AlbuM, S.-Goodwin, T.: Sylloge of Islamic Coins in the Ashmolean. 1.: The Pre-Reform Coinage of the Early Islamic Period. Oxford 2002.

ACCONCI, A. 1998: Elements of the liturgical furniture. In: Mount Nebo: New Archaeological Excavations 1967-1997. 1.: [Text.] 2.: Plans. Eds: M. Piccirillo-E. Alliata. Studium biblicum Franciscanum, Collectio maior 27. Jerusalem, 468-542.

AleksovA, B. 1997: Loca Sancta Macedoniae. The Cult of Martyrs in Macedonia from the 4th to the 9th Centuries. Editio monvmenta Macedonia 2. Skopje-Prilep.

Arslan, M.-Sevim, M.-Türkmen, M.-ŞIrin, A. 2011: Parnassos antik kenti 2010 yili kilise kurtarma kazisi. Müze Çalışmaları Ve Kurtarma Kazıları Sempozyumu 20, 189-208.

Ashrenazi, J.-Aviam, M. 2014: Small monasteries in Galilee in Late Antiquity: the test case of Karmiel. In: Knowledge and Wisdom: Archaeological and Historical Essays in Honour of Leah Di Segni. Eds: G. C. Bottini-L. D. Chrupcala-Y. Patrikh. Studium biblicum Franciscanum, Collectio maior 54. Milano, 161-178.

Aviam, M. 2002: Five ecclesiastical sites in Western Upper Galilee. In: Eretz Zafon: Studies in Galilean Archaeology. Ed.: Z. Gal. Jerusalem, 165-218, 184*-185* (Hebrew, with English summary).

Aviam, M. 2004: Jews, Pagans and Christians in the Galilee. 25 Years of Archaeological Excavations and Survey: Hellenistic to Byzantine Periods. Land of Galilee 1. Rochester.

Avi-YonaH, M. 1960: Various synagogal remains: Huldah. Bulletin of the Department of Archaeology, Hebrew University of Jerusalem 3, 57-60.

Avi-YonaH, M. 1967: The mosaic pavements. In: Excavations at Shavei Zion: The Early Christian Church. Ed.: M. W. Prausnitz. Monografie di archeologia e d'arte 2. Roma, 47-63.

Avi-Yonah, M. 1981: Art in Ancient Palestine: Selected Studies. Jerusalem.

Avner, R. 2006-2007: The Kathisma: a Christian and Muslim pilgrimage site. ARAM 18-19, 541-557.

BagATTI, B. 1969: Excavations in Nazareth. I.: From the Beginning till the XII Century. Studium biblicum Franciscanum, Collectio maior 17. Jerusalem.

Bagatti, B. 1971: The Church from the Gentiles in Palestine: History and Archaeology. Studium biblicum Franciscanum, Collectio minor 4. Jerusalem.

BagatTI, B. 1983: Antichi villaggi cristiani di Giudea e Neghev. Studium biblicum Franciscanum, Collectio minor 24. Jerusalem.

BagatTI, B. 2001: Ancient Christian Villages of Galilee. Studium biblicum Franciscanum, Collectio minor 37. Jerusalem.

BagatTi, B. 2002: Ancient Christian Villages of Judaea and the Negev. Studium biblicum Franciscanum, Collectio minor 42. Jerusalem. 
BALTy, J. 2008: Syrische Mosaikkunst. In: Die Kunst der frühen Christen in Syrien: Zeichen, Bilder und Symbole vom 4. bis 7. Jahrhundert. Eds: M. Fansa-B. Bollmann. Mainz, 98-103.

BARAMKI, D. C. 1934: An early Christian basilica at 'Ein Hanniya. QDAP 3, 113-117.

BARAMKI, D. C. 1938: An early Byzantine synagogue near Tell es Sultān, Jericho. QDAP 6, 73-76.

Baramki, D. C.-Avi-Yonah, M. 1934: An early Christian church at Khirbat 'Asida. QDAP 3, 17-19.

BARASH, M. 1974: Animal imagery in the Hanitha mosaics. IEJ 24, $222-226$.

BIEBEL, F. M. 1938: Mosaics. In: Gerasa, City of the Decapolis. An Account Embodying the Record of a Joint Excavation Conducted by Yale University and the British School of Archaeology in Jerusalem (1928-1930), and Yale University and the American Schools of Oriental Research (1930-1931, 1933-1934). Ed.: C. H. Kraeling. New Haven, 297-351.

BIRAN, A. 1959: Archaeological activities in Israel, 1958-1959. Christian News from Israel 10, 21-32.

BlanCHARD-LEMÉE, M. 1975: Maisons à mosaïques du quartier central de Djemila (Cuicul). Études d'antiquités africaines. Paris.

BlanCHARD-LemÉE, M. 2019: Les mosaïques. In: L'édifice appelé «Maison de Bacchus» à Djemila. Eds: P.-A. FévrierM. Blanchard-Lemée. Études d'antiquités africaines. Paris.

Bliss, F. J.-DickiE, A. C. 1898: Excavations at Jerusalem 18941897. London.

BRAUN, E. 1985: Soundings under a sixth century monastery at Beth Shean. 'Atiqot 17, 201-204.

Burdajewicz, J. 2017: Mosaic floors in the North-West Church of Sussita: a case-study on ten years of a joint conservation and archaeological project. In: Managing Archaeological Sites with Mosaics: From Real Problems to Practical Solutions. The 11th Conference of the International Committee for the Conservation of Mosaics, Meknes, October 24-27, 2011. Eds: D. Michaelides-A.M. Guimier-Sorbets. Firenze, 513-524.

CAmpbell, S. D. 1985: The hare mosaic: a comparative study. In: TushingHAM 1985, 87-88.

Canivet, P.-Canivet, M. T. 1987: Hūarte: sanctuaire chrétien $\mathrm{d}^{\prime}$ Apamène $\left(\mathrm{IV}^{\mathrm{e}}-\mathrm{VI}^{\mathrm{e}}\right.$ s.). Bibliothèque archéologique et historique 122. Paris.

Carandini-Ricci, A.-De Vos, M. 1982: Filosofiana. The Villa of Piazza Armerina. Palermo.

CEKA, N.-MuÇAJ, S. 2005: Byllis: its history and monuments. Tirana.

ÇELIK, Ö. 2018: Hatay, Arsuz, Kutsal Havariler Kilisesi. Müze Kurtarma Kazilari Sempozyumu 27, 265-276.

CoHEN, R. 1975: Churches. In: Encyclopedia of Archaeological Excavations in the Holy Land. 1. Ed.: M. Avi-Yonah. Oxford, 303-313.

Corbo, P. V. 1955: Gli scavi di Siyar el-Ghanam (Campo dei Pastori) e i monasteri dei dintorni. Publications of the Studium Biblicum Franciscanum 11. Gerusalemme.

Corbo, P. V. 1974: Scavi archeologici a Magdala (1971-1973). Liber Annuus 24, 5-37.

Crowfoot, J. W. 1937: Churches at Bosra and Samaria-Sebaste. British School of Archaeology in Jerusalem, Supplementary paper 4. London.
Daszewski, W. A.-Michaelides, D. 1988: Mosaic Floors in Cyprus. Biblioteca di Felix Ravenna 3. Ravenna.

Dayan, A. 2015: Monasteries in the Northern Judean Shephelah and the Samaria Western Slopes during the Byzantine and the Early Islamic Periods. [Unpublished Ph.D. Thesis, Bar-Ilan University.] Ramat-Gan (Hebrew with English summary).

Dauphin, C.-Edelstein, G. 1984: L'église byzantine de Nahariya (Israël): Étude archéologique. BYZANTINA MNHMEIA 5. Thessaloniki.

Deichmann, F. W. 1958: Ravenna: Hauptstadt des spätantiken Abendlandes. III.2. Frühchristliche Bauten und Mosaiken von Ravenna, Bildband. Wiesbaden.

Delougaz, P.-Hanies, R. C. 1960: A Byzantine Church at Khirbat al-Karak. Oriental Institute publications 85. Chicago.

DenizhanoĞullari, A.-Akgül, İ.-Akbaş, S.-Korkmaz, A. 2018: Kahramanmaraş ili dulkadiroğlu ilçesi öksüzlü mahallesi mozaikli alan kurtarma kazisi. Müze Kurtarma Kazilari Sempozyumu $27,1-12$.

DenizhanoĞUllari, A.-GÜRIÇIN, M.- ÜnLÜ, Y. 2018: Kahramanmaraş İli, Afşin İlçesi, Alimpınar Mahallesi, 288 parsel mozaik kazisi. Müze Kurtarma Kazilari Sempozyumu 27, 189-202.

Desreumaux, A.-Humbert, J. B. 2003: Les vestiges chrétiens de Khirbet es-Samra en Jordanie. In: Les églises de Jordanie et leurs mosaïques. Ed.: N. Duval. BAH 168. Beyrouth, 23-34.

DonceEl-Voûte, P. 1988: Les pavements des églises byzantines de Syrie et du Liban. Décor, archéologie et liturgie. Publications d'histoire de l'art et d'archéologie de l'Université catholique de Louvain 69. Louvain-la-Neuve.

Equini SCHNEIDER, E. 2015: Elaiussa Sebaste: 2014 excavation and conservation works. Kazi Sonuçlari Toplantisi 37/3, 479-492.

Farioli CAmpanati, R. 2009: Archeologia cristiana e protobizantina a Gortyna. La fase giustinianea della cattedrale. ASAA 87, 681-695.

FitzGerald, G. M. 1931: Beth-Shan Excavations 1921-1923. III.: The Arab and Byzantine Levels. Publications of the Palestine Section of the University Museum, University of Pennsylvania 3. Philadelphia.

FitzGerald, G. M. 1939: A Sixth Century Monastery at Beth-Shan (Scythopolis). Publications of the Palestine Section of the University Museum, University of Pennsylvania 4. Philadelphia.

GaziT, D.-Lender, Y. 1991: Horvat Be'er Shema'. Excavations and Surveys in Israel 10, 43-45.

Gonosové, A. 1987: The formation and sources of early Byzantine floral semis and floral diaper patterns examined. DOP 41, 227-237.

Gophna, R.-Beit-Arieh, I. 1997: Lod Map (80). Archaeological Survey of Israel. Jerusalem (in Hebrew).

Greenhut, Z. 1998: Horvath Hermeshit (1988-1990). 'Atiqot 34, 121-172, 9*-10* (in Hebrew, with English summary).

Gudovitch, SH. 1996: A Byzantine building at the foot of Horbat Sokho. 'Atiqot 28, 17*-23*, 197 (in Hebrew, with English summary).

Hamilton, R. W. 1959: Khirbat al Mafjar. An Arabian Mansion in the Jordan Valley. Oxford.

Hirschfeld, Y. 2004: Excavations at Tiberias, 1989-1994. Israel Antiquities Authority reports 22. Jerusalem.

Hirschfeld, Y. 2005: Roman, Byzantine, and Early Muslim Tiberias: A Handbook of Primary Sources. Tiberias. 
HoddinotT, R. F. 1963: Early Christian Churches in Macedonia and Southern Serbia. A Study of the Origins and the Initial Development of East Christian Art. London.

KenYon, K. M. 1967: Jerusalem: Excavating 3000 Years of History. New Aspects of Antiquity. London.

KHAMIS, E. 2010: The metal artefacts. In: Ramla: Final Report on the Excavations North of the White Mosque. Ed.: O. Gutfeld. QEDEM 51. Jerusalem, 279-285.

KitZINGER, E. 1977: Byzantine Art in the Making. Main Lines of Stylistic Development in Mediterranean Art, 3rd to 7th Century. Mass. Cambridge.

KLETTER, E. 2010: Late Byzantine remains near Shiqmona: a monastery, a cemetery and a winepress. 'Atiqot 63, 147-182.

Lassus, J. 1938a: La mosaïque du Phénix provenant des fouilles d'Antioche. Monuments et mémoires de la Fondation Eugène Piot 36, 81-122.

LASsus, J. 1938b: L'église cruciform, Antioche-Kaoussié 12-F. In: Antioch-on-the-Orontes. II.: The Excavations, 1933-1936. Ed.: R. Stillwell. Publications of the Committee for the Excavation of Antioch and its Vicinity. Princeton, 5-44.

LAVIN, I. 1963: The hunting mosaics of Antioch and their sources. A study of compositional principles in the development of early mediaeval style. DOP 17, 179-286.

LeVI, D. 1947: Antioch Mosaic Pavements. 1.: Text. 2.: Plates. Publications of the Committee for the Excavation of Antioch and its Vicinity 4. Princeton.

LoffredA, S. 1985: Recovering Capharnaum. Studium biblicum Franciscanum, Guides 1. Modena.

LoffredA, S.-CAFARnAO, V. 2005: Documentazione fotografica degli scavi (1968-2003). Studium biblicum Franciscanum, Collectio maior, 44. Jerusalem.

Madden, A. M. 2014: Corpus of Byzantine Church Mosaic Pavements in Israel and the Palestinian Territories. Colloquia antiqua 13. Leuven.

Magen, Y. 2012: The central church at Beit 'Anun. In: Christians and Christianity. IV.: Churches and Monasteries in Judea. Ed.: N. Carmin. Judea and Samaria publications 16. Jerusalem, 121168.

Magen, Y.-Aharonovich, E. 2012: The northern churches at Shiloh. In: Christians and Christianity. III.: Churches and Monasteries in Samaria and Northern Judea. Ed.: N. Carmin. Judea and Samaria Publications 15. Jerusalem, 161-208.

Magen, Y.-Har-Even, B.-Sharukh, I. 2012: A Roman tower and a Byzantine monastery at Khirbet el-Qașr. In: Christians and Christianity. IV.: Churches and Monasteries in Judea. Ed.: N. Carmin. Judea and Samaria publications 16. Jerusalem, 247298.

Maltoni, R. B.-Cardascia, M.-Corbara, F.-Zingaretti, S. 2008: Domus dei Tapetti di Pietra. Ravenna.

Michel, A. 2001: Les églises d'époque byzantine et umayyade de Jordanie (provinces d'Arabie et de Palestine), Ve-VIIIe siècle. Architecture et liturgie. Bibliothèque de l'Antiquité Tardive 2. Turnhout.

MŁynarCZyK, J.-BurdajeWiCZ, M. 2005: North-West church in Hippos (Sussita), Israel: Five years of archaeological research. Eastern Christian Art 2, 39-58.
NalÂN Yasti, M.-ÇOŞAR, H.-TÜrkmenoĞLU, A. 2016: Osmaniye ili, Düziçi ilçesi, Olukluçunur Köyü mozaikli alan kurtarma kazisi 2015. Müze Kurtarma Kazilari Sempozyumu 25, 653-664.

NAssar, M.-AL-MuHeISEN, Z. 2010: Geometric mosaic pavements of Yasileh in Jordan. PEQ 142, 182-198.

Negrelli, C. 2018: Rimini, Piazza Ferrari. In: Medioevo svelato. Storia dell'Emilia-Romagna attraverso l'archeologia. A cura di: S. Gelichi-C. Cavallari-M. Medica. Bologna, 281289.

NetZer, E. 1990: The Byzantine churches of Herodion. In: Christian Archaeology in the Holy Land: New Discoveries. Essays in Honour of Virgilio C. Corbo, OFM. Eds: G. C. BottiniL. Di Segni-E. Alliata. Studium biblicum Franciscanum, Collectio maior 36. Jerusalem, 165-176.

Netzer, E.-Birger-Calderon, R.-Feller, A. 1993: The churches of the Herodium. In: Ancient Churches Revealed. Ed.: Y. Tsafrir. Jerusalem, 219-232.

Oren, R.-Scheftelowitz, N. 2000: Kefar Truman. HA-ESI 111, $47^{*}$.

Ovadiah, A. 1970: Corpus of the Byzantine Churches in the Holy Land. Theophaneia: Beiträge zur Religions- und Kirchengeschichte des Altertums 22. Bonn.

Ovadiah, A. 2011: Conservative approaches in the ancient synagogue mosaic pavement in Israel: The case of 'Ein Gedi and Sepphoris/Zippori. In: $11^{\text {th }}$ International Colloquium on Ancient Mosaics. October $16^{\text {th }}-20^{\text {th }}, 2009$, Burssa Turkey. Ed.: M. Sahin. Istanbul, 693-700.

Ovadiah, R.-Ovadiah, A. 1987: Hellenistic, Roman and Early Byzantine Mosaic Pavements in Israel. Bibliotheca archaeologica 6. Rome.

PAtrich, J. 2011: Studies in the Archaeology and History of Caesarea Maritima. Caput Judaeae, Metropolis Palaestinae. Ancient Judaism and Early Christianity/Arbeiten zur Geschichte des antiken Judentums und des Urchristentums 77. Leiden-Boston.

PATRICH, J. 2018: A Walk to Caesarea: A Historical-Archaeological Perspective. Treasures of the Past/The David and Jemima Jeselsons Library. Jerusalem.

PiCCIRILlo, M. 1986: Die Mosaiken von Justinian bis Jazid II. In: Byzantinische Mosaiken aus Jordanien. Ed.: H. Buschhausen. Katalog des Niederösterreichischen Landesmuseums N.F. 178. Wien, 27-121.

PICCIRILlo, M. 1994: I mosaici del complesso di Santo Stefano. In: Gli scavi del complesso di Santo Stefano. Eds: M. PiccirilloE. Alliata-I. Umm al-Rasas Mayfa'ah. Studium biblicum Franciscanum, Collectio maior, 28. Jerusalem, 121-164.

PicCirillo, M. 1997: The Mosaics of Jordan. American Center of Oriental Research publications 1. Amman.

PicCIRILlo, M. 1998: The Mosaics. In: Mount Nebo. New Archaeological Excavations 1967-1997. Eds: M. PiccirilloE. Alliata. Studium biblicum Franciscanum, Collectio maior 27. Jerusalem, 264-371.

PRIGNAUd, J. 1963: Une installation monastique byzantine au Khan Saliba. RB 70, 243-254.

Richmond, E. T. 1936: Basilica of the Nativity. Quarterly of the Department of Antiquities of Palestine 5, 75-81. 
Segal, A.-MŁynarczyk, J.-Burdajewicz, M.-Schuler, M.EISENBERG, M. 2005: Hippos-Sussita: Sixth Season of Excavations. Haifa.

SCHICK, R. 1995: The Christian Communities of Palestine from Byzantine to Islamic Rule. A Historical and Archaeological Study. Studies in Late Antiquity and Early Islam 2. Princeton.

SchneIDER, A. M. 1937: The Church of the Multiplication of the Loaves and Fishes at Tabgha. London.

StrubE, C. 2008: Al-Andarin/Androna: site and setting. In: Residences, Castles, Settlements: Transformation Processes from Late Antiquity to Early Islam in Bilad al-Sham. Proceedings of the International Conference held at Damascus, 5-9 November 2006. Eds: K. Bartl-A. R. Moaz. Orient-Archäologie 24. Rahden/Westf, 57-71.

Strube, C. 2010: Al Andarin, das antike Androna. In: Byzanz Das Römerreich im Mittelalter. 2.1.: Schauplätze. Eds.: F. Daim-J. Drauschke. Monographien des Römisch-Germanischen Zentralmuseums 84/2.1. Mainz, 211-243.

Syon, D. 2002: The church. In: Eretz Zafon: Studies in Galilean Archaeology. Ed.: Z. Gal. Jerusalem, 255-261, $186^{*}-187^{*}$ (Hebrew, with English summary).

SwITH, E. 2019: Style and Function in Roman Decoration: Living with Objects and Interiors. Abingdon-New York, $2^{\text {nd }}$ ed.

TAHA, H. 1997: A salvage excavation at the 'Abudiyah Church in Abud - Samaria. Liber Annuus 47, 359-374.

TAL, O.-TAXEL, I. 2015: Samaritan Cemeteries and Tombs in the Central Coastal Plain. Archaeology and History of the Samaritan Settlement outside Samaria (ca. 300-700 CE). Ägypten und Altes Testament 82. Münster.

Talgam, R. 2014: Mosaics of Faith: Floors of Pagans, Jews, Samaritans, Christians, and Muslims in the Holy Land. Treasures of the past. Jerusalem-University Park.

TAlgam, R. 2020: A seventh-century CE mosaic floor at Pi Mazuva. 'Atiqot 99, 57*-66*, 185-187 (in Hebrew, with English summary).

TChalenko, G. 1979-1990: Églises syriennes à bema. Églises de villages de la Syrie de Nord. 1-3. BAH 105. Paris.

Themelis, P. G. 2004: Eisgōgē è prōtovyzantinē basilikē o prōtovyzantinos oikismos. Synophē istorikōn symperasmatōn. In: Prōtovyzantinē Eleutherna 1. Ed.: P. G. Themelis. Athens, $35-110$.

Tsafrir, Y.-Foerster, G. 1997: Urbanism at Scythopolis-Bet Shean in the Fourth to Seventh Centuries. DOP 51, 85-146.

Tsafrir, Y.-Di Segni, L.-GreEn, J. 1994: Tabula Imperii Romani. Iudaea-Palaestina: Eretz Israel in the Hellenistic, Roman and Byzantine Periods. Maps and Gazetteer. Jerusalem.

TURQUeTY-PARISET, F. 1982: Fouilles à la municipalité de Beyrouth (1977). Syria 59, 1-76.

TürkmenoĞlu, A.-Kavuklu, Z.-Çoşar, H.-Arinç, U. 2018: Osmaniye, Düziçi, Cumhuriyet Mahallesi, mozaikli alan kurtarma kazisi. Müze Kurtarma Kazıları Sempozyumu 27, 25-38.

Tushingham, A. D. 1985: Excavations in Jerusalem 1961-1967. I. Toronto.

TzAFERIS, V. 1975: The archaeological excavation at Shepherds' Field. Liber Annuus 25, 5-288.

TzaferIs, V. 1983: The Excavations of Kursi-Gergesa. 'Atiqot ES 16. Jerusalem.

TzAFERIS, V. 1985a: An early Christian church complex at Magen. BASOR 258, 1-15.

TzAFERIS, V. 1985b: Mosaics and inscriptions from Magen. BASOR 258, 17-32.

Tzaferis, V. 1993: An early Christian church at Khirbet Samra. In: Studies in the Archaeology and History of Ancient Israel in Honour of Moshe Dothan. Eds: M. Heltzer-A. SegalD. Kaufman. Haifa, 227-249.

Urano, S.-Fukatsu, Y.-YÜCEL, T. 2016: III. Kent bazilikasi. In: Tlos 2015 kazi etkinlikleri. Kazi Sonuçlari Toplantisi 38/1, 412414.

YAVUZKIR, A. 2016: Şanliurfa ili siverek ilçesi aşaği yalankoz mozaik kurtarma kazisi. Müze Kurtarma Kazıları Sempozyumu 25, 215-234.

YeIVIN, S. 1960: A Decade of Archaeology in Israel: 1948-1958. Publications de l'Institut historique et archéologique néerlandais de Stamboul 8. Istanbul.

YeIvin, Z. 1992: Excavations at Carmiel (Khirbet Bata). 'Atiqot 21, 190-128.

YiLmaZ, M. S.-FistıKÇı, A. 2015: Korucak mozaikli alan ve kaya odasi mezari kurtarma kazisi. Müze Kurtarma Kazilari Sempozyumu 24, 221-232.

VAn Elderen, B. 1972: An early Byzantine inscription found near Ajlun. Annual of the Department of Antiquates of Jordan 17, 73-75.

VITTO, F. 2008: A Byzantine church at Qiryat Ata. 'Atiqot 60, 165176.

Weber, T. M. 2010: Syrien, Ägypten und Aksum. Das "sanctuaire carré" - eine Sonderform des Altarraumes in der frühchristlichen Sakralarchitektur Westasiens und Nordafrikas. In: Krise und Kult. Vorderer Orient und Nordafrika von Aurelian bis Justinian. Eds.: D. Kreikenbom-K.-U. Mahler-P. SchollmeyerT. M. Weber. Millennium-Studien/Millennium studies 28 . Berlin-New York, 207-254.

Weiss, Z.-TAlgam, R. 2002: The Nile festival building and its mosaic. Mythological representations in early Byzantine Sepphoris. In: The Roman and Byzantine Near East. 3. Ed.: J. H. Humphrey. JRA Supplementary series 49. Portsmouth, 55-90.

ZAKZOUK, A. R. 2008: Stadt und Museum von Hama. In: Die Kunst der frühen Christen in Syrien. Zeichen, Bilder und Symbole vom 4. bis 7. Jahrhundert. Eds: M. Fansa-B. Bollmann. Mainz, 130-135.

ZviLICHOvsKY, V. 1960: Kfar Truman. RB 67, 402.

Open Access. This is an open-access article distributed under the terms of the Creative Commons Attribution 4.0 International License (https://creativecommons.org/ licenses/by/4.0/), which permits unrestricted use, distribution, and reproduction in any medium, provided the original author and source are credited, a link to the CC License is provided, and changes - if any - are indicated. (SID_1) 